Article

\title{
Municipal Sustainability Influence by European Union Investment Programs on the Portuguese Local Government
}

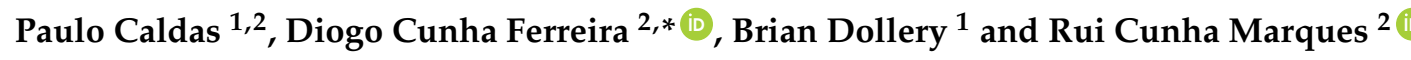 \\ 1 School of Business, University of New England, Armidale, NSW 2351, Australia; \\ pauloacaldas@outlook.pt (P.C.); bdollery@une.edu.au (B.D.) \\ 2 CESUR, CERis, Instituto Superior Técnico, University of Lisbon, 1649-004 Lisbon, Portugal; \\ rui.marques@tecnico.ulisboa.pt \\ * Correspondence: diogo.cunha.ferreira@tecnico.ulisboa.pt; Tel.: +351-218-418-394
}

Received: 16 February 2018; Accepted: 19 March 2018; Published: 21 March 2018

\begin{abstract}
The assessment of the impact of European Structural and Investment Funds (ESIF) on Portuguese local government and which factors determine it is important given the magnitude of funds involved. As part of this larger question, this paper considers whether the holistic sustainability of local authorities-as measured by a Council Sustainability Index-can influence the impact of ESIF on the performance of Portuguese councils and which factors best explain these performance differences. Using a geometric distance function jointly with the Hicks-Moorsteen index, we investigate and present a conclusion on the differential impact of ESIF on sustainable and non-sustainable Portuguese councils over the period 2000 to 2014. Our findings also suggest that ESIF should continue fostering economic and social development at the local level regardless of council size or regional location since overall development will flow from this economic and social structural adjustment strategy.
\end{abstract}

Keywords: European Structural and Investment Funds; municipal sustainability; Council Sustainability Index (CSI); Portuguese local government

\section{Introduction}

As in many European countries, Portuguese local government is responsible for major public investments, as well as for a wide range of local services. They deal with a range of public policy issues and functions that support economic development and improve the quality of life [1]. Local council performance is thus especially important in an era of economic uncertainty and increasing complexity [2]. Moreover, performance measurement and benchmarking in local government help to align the goals of governments with the goals of citizens [3]. Portuguese councils play a pivotal role since they are responsible for almost $30 \%$ of total investment, $15 \%$ of public employment, and $3 \%$ of public debt [4].

The European Structural and Investment Funds (ESIF), established in 1986, plays a crucial role in the economic and social development of Portugal, especially at the local level. An important question in this regard hinges on determining whether ESIF have resulted in significant improvements in municipality performance and in the quality of life of residents. A thorough survey on the 308 Portuguese councils over the period 2000 to 2014, corresponding to the two final European Structural and Investment Funds (ESIF) (ESIF III and National Strategic Reference Framework (NSRF)), identified those aspects of EU programs which improved the performance and sustainability of Portuguese local government, namely competitiveness, territory development, and education factors [5]. Moreover, it highlighted the significance of this impact given the context of major 
productivity divergences between countries [6] and increasing political integration to guarantee, in the medium term, economic and social cohesion between all European Countries [7].

By contrast, council size and regional location had no direct influence on performance. However, development "catch up" and "growth convergence" seemed significant [8].

In view of previous analysis, the current research analyzes the impact of the ESIF on the 308 Portuguese councils for the period 2000 to 2014 [9]. In an empirical contribution to existing literature on this question, the paper investigates whether the holistic sustainability level of Portuguese local councils influenced that uneven impact. Put clearly, do significant differences exist between sustainable and non-sustainable councils with respect to the impact of EU funding programs? Using a rigorous model embodying a geometric distance function (GDF) and the Hicks-Moorsteen Index (HMI), we investigate the different impact of ESIF on sustainable and non-sustainable Portuguese councils.

We have reached some interesting conclusions: first, for both EU programs, the difference in the investment impact was not significant regardless of whether a council exhibited higher or lower levels of sustainability, notwithstanding the importance of the EU programs to the structural adjustment of the Portuguese economy. Second, the size and regional location of local authorities seem to have no direct influence on the impact of EU investments. Finally, we found that both efficiency and productivity are higher on ESIF III (2000-2006) than under NSRF (2007-2013) — for sustainable and non-sustainable councils alike-because of the stronger effects of ESIF III on the economic and social circumstances of residents, including increased competitiveness, spatial development, and the human potential of individual councils and specific regions.

The paper is divided into six main sections. Section 2 considers the ESIF contribution to Portuguese local authority performance and sustainability. Section 3 presents a holistic sustainability perspective of local government evaluation by means of a new Council Sustainability Index (CSI), which was recently applied to Portuguese local government. Section 4 outlines the model used to test different council investment impacts based on sustainability. Section 5 analyzes the Portuguese council EU program impact on key performance and sustainability indicators, distinguishing between sustainable and non-sustainable councils for ESIF III (2000-2006) and NSRF (2007-2013). The paper concludes with some brief comments in Section 5 .

\section{European Structural Investment and Funds Impact on Municipal Performance and Sustainability}

\subsection{European Structural Investment and Funds Impact on Municipal Performance}

European structural investment funds (ESIF) represent one of the main instruments which the EU uses to sustain regional development and eliminate disparities between member states [8].

In Portugal, public investment has seen an increase of competitiveness and an improvement in the quality of life made over the past three decades which would have been impossible without ESIF. Table A1 in the Appendix A summarizes the ESIF implemented over 1986-2013 in Portugal.

Structural and cohesion programs are implemented under a common regulatory framework, but in widely differing national and regional circumstances. Programs comprise a range of interventions, targeting physical infrastructure, economic development, human resources, innovation, and technology, as well as environmental improvement, through a mix of financial instruments and many different types of beneficiary. In addition, there is also co-financing of EU funds through national public or private funding which originates from several different organisations and schemes [10].

EU cohesion policy effects have been considered mainly by empirical work on the investment impact on citizens' economic and social conditions, regional growth, and global convergence. Table 1 provides a synopsis of empirical research to date. 
Table 1. Research literature on EU investment impact and economic and social convergence.

\begin{tabular}{|c|c|}
\hline Authors & Main Findings \\
\hline Sala-i-Martin [11] & $\begin{array}{l}\text { USA, Japan, and European Countries tend to converge at a rate of } \\
\text { approximately } 2 \% \text { per year. Interregional distribution of income in all } \\
\text { countries has shrunk over time. }\end{array}$ \\
\hline Delhey [12] & "Catch-up" process is facilitated by EU integration policies not guaranteed. \\
\hline Boldrin et al. [13] & $\begin{array}{l}\text { Stability and inequality of EU regional distribution of income per capita. EU } \\
\text { regional funds impact is positive on GDP per capita growth of poorer } \\
\text { countries. }\end{array}$ \\
\hline Atkinson et al. [14] & $\begin{array}{l}\text { Proposal of alternatives to the EU indicators for social inclusion (distribution } \\
\text { of income, social transfers, regional disparities, persistence of poverty, } \\
\text { unemployment, and educational rate), such as housing, health, access to } \\
\text { essential services, and social participation. }\end{array}$ \\
\hline Ederveen et al. [15] & $\begin{array}{l}\text { Structural funds are globally (13 regions of Europe) ineffective. Structural } \\
\text { funds are only effective for countries with a proper "institutional framework", } \\
\text { based on transparency, control of corruption, good governance, and } \\
\text { institutional quality. }\end{array}$ \\
\hline Cappelen et al. [16] & $\begin{array}{l}\text { EU regional policy is effective and positively related to accompanying } \\
\text { policies that improve the competence of the receiving environments. }\end{array}$ \\
\hline Beugelsdijk and Eiffnger [17] & $\begin{array}{l}\text { Structural funds have a positive impact based on institutional capacity. Moral } \\
\text { hazard and substitution effects may result from use of structural funds. } \\
\text { Structural funds contribute to fewer interregional disparities. }\end{array}$ \\
\hline Dall'erba and Le Gallo [18] & $\begin{array}{l}\text { Convergence takes place, but the funds have no impact on it. Investments } \\
\text { targeted to peripheral zones never spill over to neighbors. }\end{array}$ \\
\hline Fritsche and Kuzin [19] & $\begin{array}{l}\text { Regional clusters exist in the consumer price level. Existence of convergence } \\
\text { clubs, including a fast-growing countries club, without strong regional } \\
\text { linkages. }\end{array}$ \\
\hline Bartkowska and Riedl [20] & $\begin{array}{l}\text { Existence of convergence clubs, indicating that European regions form six } \\
\text { separate groups converging to their own steady state paths. The level of initial } \\
\text { conditions such as human capital and per capita income plays a crucial role in } \\
\text { determining the formation of convergence clubs among European regions. }\end{array}$ \\
\hline Borsi and Metiu [8] & $\begin{array}{l}\text { Economic "catch-up" exists based on institutional changes and } \\
\text { macro-economic adjustment processes. No overall real income per capita } \\
\text { growth; the existence of sub-groups that converge to different steady states. } \\
\text { Regional linkages play an important role in determining the formation of } \\
\text { convergence clubs. A clear separation between the new and the old EU } \\
\text { member states in the long run. }\end{array}$ \\
\hline
\end{tabular}

Using cross-sectional regressions, Sala-i-Martin [11] found that regional growth and convergence patterns in the EU were not markedly different from those in other federations which lacked such an extensive cohesion program. Several other authors, including Boldrin et al. [13], Ederveen et al. [15], Cappelen et al. [16], Beugelsdijk and Eiffnger [17], Dall'erba and Le Gallo [18], Fritsche and Kuzin [19], and Bartkowska and Riedl [20], using different parametric and non-parametric methods, empirically examined ESIF expenditure and GDP per capita growth, with inconclusive results about growth convergence, but almost all of them highlighted the importance of institutional capacity, as demonstrated above.

Delhey [12] analysed Ireland, Greece, Portugal, and Spain, concluding that EU integration facilitates processes of catching up but it does not guarantee them. This was demonstrated by using three indicators: (1) GDP per capita adjusted for purchasing power; (2) social security spending in relation to GDP (proxing the level of social protection); and (3) citizen satisfaction with life in general and living conditions. In general, EU policy aims to improve economic and social conditions, as well as life circumstances in a broader sense, using a wider perspective by employing quality of life concepts [21,22]. 
Atkinson et al. [14] measured specific social outcomes in EU member states, suggesting various extensions and alternatives to existing EU indicators for social inclusion (distribution of income, social transfers, regional disparities, persistence of poverty, unemployment, and educational rate), including housing, health, access to essential services, and social participation.

Borsi and Metiu [8] concluded that economic "catch up" exists, but it depends on institutional changes and macroeconomic adjustment. They did not find any overall economic convergence, but instead distinct sub-groups of countries which converged to different steady states. The main conclusion of this study is that EU cohesion policy contributes to improving development in different EU countries, but in a varied way, based on differences in community budget, institutional capacity, the structure of national economies, and the kind of investments chosen.

To sum up, the findings synthetically presented above demonstrated that the "Catch-up" process is facilitated by EU integration policies, but not guaranteed. Moreover, differentiated EU investment impact and economic and social convergence depend, in most cases, on the "proper institutional capacity" of each country and region to absorb and convert EU programs and funds intervention into economic and social sustainable growth. In Portugal, EU adhesion contributed to economic, social, and cultural openness, perhaps even to a rupture through structural modernization after fifty years of dictatorship in Portugal (until 1974).

\subsection{Understanding the Importance of "Holistic" Sustainability}

Performance assessment is nonetheless important, because it allows for an effective inter-council comparison in terms of value for money of the service provision on the one hand, and management performance in terms of happiness and community satisfaction on the other hand [23]. Efficiency focuses attention on the inputs and outputs used and produced, whereas effectiveness concentrates on community satisfaction with the council services and investment capacity for sustainable development.

Sustainable development forms a capstone of the approach we advocate for local government. In this scope, Bartelmus [24] presented the foundations of sustainable development, contending that after repeated failure of the International Development Strategies of the United Nations, an alternative development concept was necessary. The World Conservation Strategy was the first to define "sustainable development" by means of conserving living resources [25]. The United Nations later established the World Commission on Environment and Development (WCED) in 1985 to investigate the causes and remedies of development failures. The WCED defined "sustainable development" as a process which meets the needs of the present without compromising the ability of future generations to meet their own needs, thereby joining environmental objectives and economic growth objectives [26].

This general definition of sustainability forms the basis for our local government evaluation approach. Thus, in contrast to the narrow financial viability, community sustainability would embrace wider economic, political, and sociological attributes. In its broader connotation, "holistic sustainability is the ability of a local authority to function effectively over the long term" [27].

In Europe, several conceptual frameworks or methods to develop local sustainability indicators have been carried out (for an overview of similar projects, see Pires et al. [28]).

Key financial performance indicators, ratios, and indexes are only broadly indicative of the real situation of individual councils. Local government sustainability should be assessed in a broader perspective, in terms of a council's ability to perform effectively over the long term and the satisfaction of community interests, as presented below in Table 2 [23]. 
Table 2. Different holistic sustainability definitions.

\begin{tabular}{lll}
\hline \multicolumn{1}{c}{ Author } & Date & \multicolumn{1}{c}{ Concepts and Definitions } \\
\hline Vetter and Kersting [29] & 2003 & Economic and political attributes must be considered. \\
\hline Aulich [30] & 2005 & $\begin{array}{l}\text { Local government dual role (democratic organization and service } \\
\text { provider); the importance of efficient service provision together with } \\
\text { effective local democracy. }\end{array}$ \\
\hline Dollery, Garcea and Lesage [31] & 2008 & $\begin{array}{l}\text { Five main pillars of local government sustainability: demographic } \\
\text { factors, council revenue, council expenditure, council financial } \\
\text { management, and council governance. }\end{array}$ \\
\hline Dollery, Crase and Grant [32] & 2011 & $\begin{array}{l}\text { The importance of local democracy (good governance), local social } \\
\text { capital (citizens "sense of community" and "sense of place"), and } \\
\text { local government capacity (well-functioning elected leadership and } \\
\text { administrative and technical expertise). }\end{array}$ \\
\hline Bell and Morse [33] & 2013 & $\begin{array}{l}\text { Measuring sustainability at local and regional levels. New ways of } \\
\text { thinking about sustainability indicators. }\end{array}$ \\
\hline Warburton [34] & 2013 & $\begin{array}{l}\text { Community participation and sustainable development. The } \\
\text { connections between environmental action and community-based } \\
\text { activities. }\end{array}$ \\
\hline Wates [35] & 2014 & $\begin{array}{l}\text { New methods of community planning. How communities become } \\
\text { safer, stronger, wealthier, and more sustainable. }\end{array}$ \\
\hline
\end{tabular}

The concept of local government sustainability is indeed much broader than simple financial sustainability. Communities or "holistic" sustainability really matters concerning local government evaluation [36].

Councils currently compete for practical and tangible issues, such as financial resources and new investments. However, financial and investment decisions, transparency, corruption control, and public participation and satisfaction gained an objective pathway and a trustful local government assessment tool.

Therefore, a fresh approach, conceptualizing and implementing a Councils' Sustainability Index (CSI), is required to address the problems of strategic management, in addition to funding and sustainable development in local government.

\subsection{A Portuguese Council Sustainability Index (CSI)}

The development and application of a new CSI to Portuguese local government represented an important step forward in improving the informational basis for future policymaking.

The CSI constructed by Caldas et al. [23] developed weighted evaluation criteria in conjunction with a range of stakeholders, including municipal officeholders and empirical experts on local government. Four major aspects of council sustainability were combined (governance, government effectiveness, economic and social development, as well as financial sustainability) containing 25 specific criteria. Figure 1-the "value tree" — summarizes all the elements comprising the CSI, together with their respective weights [23]. Caldas et al. argued that their CSI approach, which was applied to Portuguese local government, can be employed for the evaluation of any local government system mutatis mutandis [37].

Several dimensions of local government are aggregated in CSI using a Multi-criteria Decision Analysis model, encompassing council management, stakeholders, and community objectives. Integrating different stakeholders' interests contributes to an accurate evaluation of council sustainability, needs, and performance, and provides guidelines for better local government decision-making. Alternative methods (e.g., direct scoring methods or other probabilistic, empirical, and knowledge-based techniques) would have resulted in failure of the main goal of this investigation (i.e., to determine overall assessment of Portuguese local government performance and sustainability). 


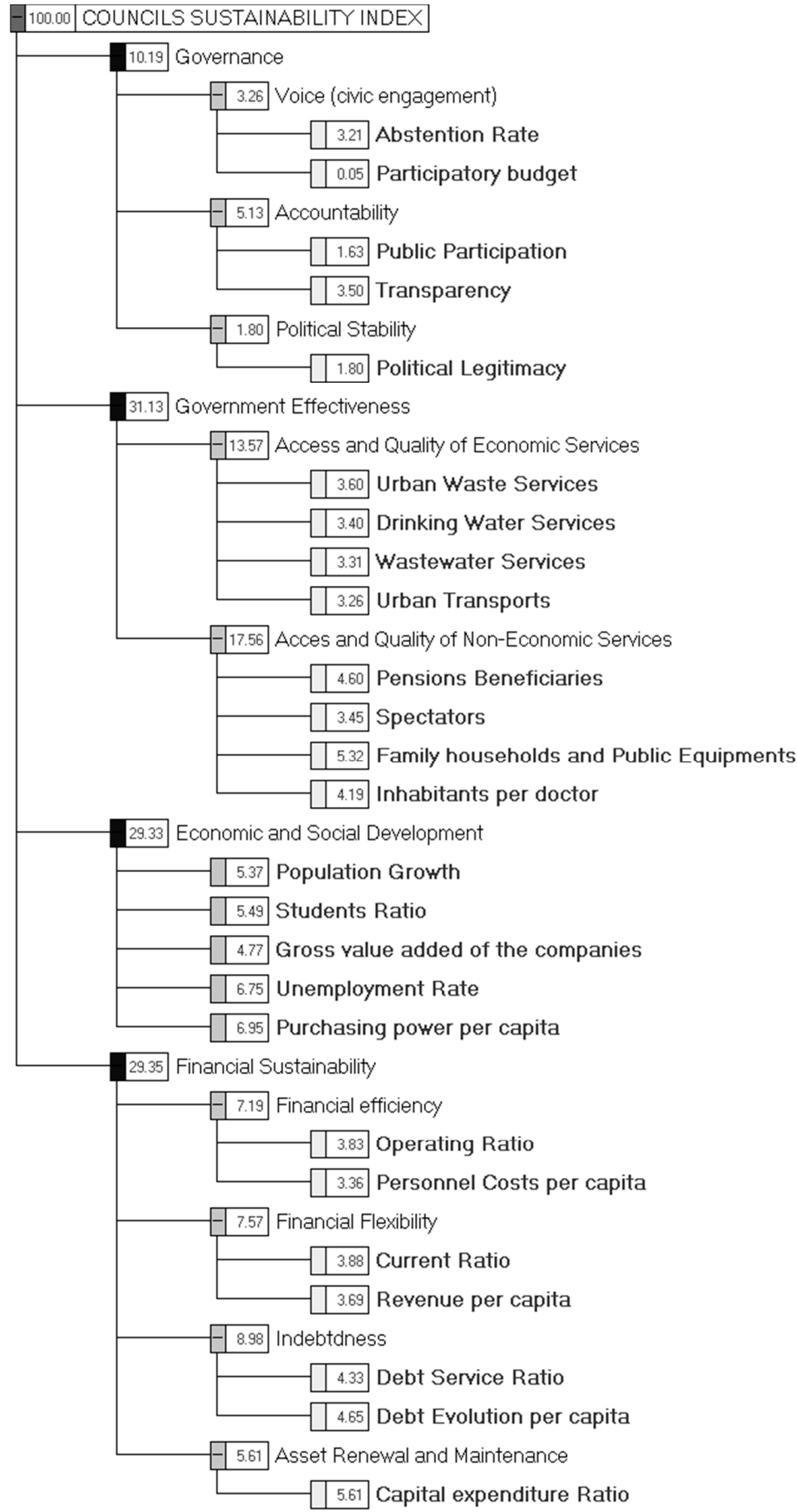

Figure 1. CSI Value Tree with CSI weights (source: [23]).

It is important to recognize, however, that the CSI model possesses various limitations, requiring further attention. While this paper considered financial sustainability, governance, and sustainable development, other variables could also be assessed (or weighted in a different manner) to measure "holistic sustainability". Additionally, the prospect of applying the CSI beyond Portugal is important from a policy perspective. The crucial issue on this matter is that institutional framework and contextual 
information of the region/country analyzed is imperative to determine the most adequate DMG, as well as the variables selection. Consideration of different forms of governance and different local modus operandi should determine a customized CSI. This could address different institutional realities. We would, then, be able to compare holistic sustainability ratios and local government performance. Simultaneously, we could assess the effectiveness of CSI format to evaluate local government performance and sustainability worldwide.

Tables A2 and A3 in the Appendix A detail the most sustainable councils (best $10 \%$ of performers) and non-sustainable councils (worst $10 \%$ of performers), respectively. These groupings form the two different clusters examined in this paper with respect to EU funding program impact. Considering decile (top and bottom line of CSI), rather than, for example, quartile, allowed us to catch more significant differences on the level of council sustainability, based on financial and non-financial factors. Thus, this option allowed a clearer distinction of the potential capacity each council might have for investments and funds absorption and development (conceiving that a priori top sustainability predetermines higher EU impact and bottom sustainability lower EU impact).

\section{Methodological Considerations}

The methodology employed in the present study follows Ferreira and Marques [38]. Consider a council whose performance relative to a set of different groups (or clusters) is being assessed. Because one should compare likes with likes, those authors proposed a three-cycle Monte Carlo procedure to search for comparable potential benchmarks (best practices) in the different clusters. This procedure avoids the endogeneity problem, which can be very serious. Gaps between achieved benchmarks disentangle potential frontier shifts, and efficiency spreads. The former discloses which cluster is the most productive, whereas the latter reflects the consistency of the efficiency levels of each group. Hence, Ferreira and Marques [38] augmented the radial HMI to account for any inefficiency source and benchmarking adopted model. The new index of productivity HMI was, then, coupled with the three-cycle Monte Carlo procedure to obtain a large set of efficiency estimates and, for that reason, if offers robust and statistical tools for efficiency and productivity analysis. The framework is summarized in Figure 2 and detailed hereinafter.

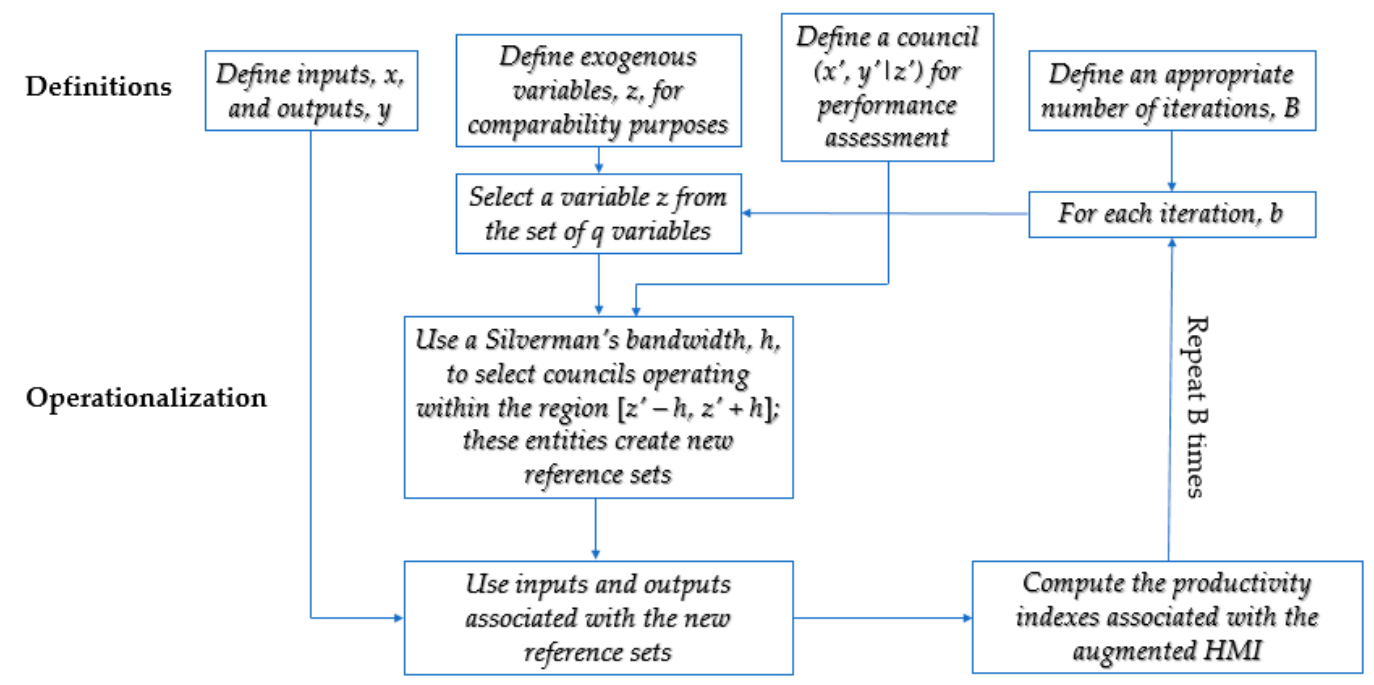

Figure 2. Summary of the Monte-Carlo procedure for efficiency and productivity assessment of clusters.

In general, empirical studies rely either on parametric or nonparametric methods, creating full frontiers. In other words, entire samples are considered in these analyses. However, and regarding nonparametric methods—data envelopment analysis (DEA) and free disposal hull (FDH) [39]—full frontiers are particularly prone to the presence of outliers, extreme values, and the curse of 
dimensionality, which biases the results by overestimating the extent of inefficiency. The adoption of partial frontiers, like order- $m$ and order- $\alpha$ [40], seems to be more appropriate for (in) efficiency assessment in local government since they are less sensitive to these effects. Furthermore, the advantage of GDF-HMI is that it is a true measure of the total factor productivity and it is model-free because it is defined by means of targets (instead of direct measures of efficiency, like Shephard's radial distances). Thus, any model able to compute efficient targets can be utilized with GDF-HMI. One example of such a model is the directional order- $\alpha$, as mentioned.

After a cluster has been selected as the reference, say $A$, we then seek comparable decision-making units (councils) in another cluster, say $B$. Comparability is based on a set of variables, like demographic variables, the scope of services, and the like. In the present context, we use a single variable: population size. Statistical robustness is ensured through bootstrapping iterations (15,000 iterations in our case) (see Ferreira and Marques [38] for details of this procedure).

It is important to distinguish between the two main performance measures: efficiency and productivity.

Definition 0 (Efficiency and productivity). Consider two groups (clusters) of councils, whose performance is being assessed. Each group has a specific frontier characterizing its underlying production technology. Benchmarks (or best practices) of each technology are placed onto the corresponding frontier. Thus:

- Efficiency focuses on the relative position of the councils from a group with respect to their own corresponding frontier; the more below the frontier, the more inefficient these councils.

- Productivity concerns the relative position of both frontiers (i.e., technologies); one cluster is more productive than the other if the former benchmarks can produce more outputs with fewer inputs than the best practices of the other group [41]. Let us consider two clusters, $A=\{$ non-sustainable councils $\}$ and $B=\{$ sustainable councils\}, as achieved through the CSI approach (vide supra). Each cluster is totally characterized by a set of $m$ inputs (consumed resources), $X_{i}, i=1 \ldots, m$, and s produced outputs (goods and/or services), $Y_{r}$, $r=1, \ldots$, s. Suppose these clusters have sizes $n_{A}$ and $n_{B}$, respectively. These $n_{*}$ councils are responsible for the production process, say $\Psi_{A}=\left\{1, \ldots, j_{A}, \ldots, n_{A}\right\}$ and $\Psi_{B}=\left\{1, \ldots, j_{B}, \ldots, n_{B}\right\}$, and at the same time they face a set of $q$ exogenous variables, $Z_{p}, p=1, \ldots, q$. Some of those councils are more efficient than the others in the very same cluster. The Pareto-efficient councils are placed in the efficient frontier (or technology), $\partial \Psi_{A}$ and $\partial \Psi_{B}$, which in turn can be constructed via non/semi-parametric tools, such as data envelopment analysis (DEA)-like methods. Now, consider a single council $l_{0}$ from a specific cluster, say $A$, and denote it by $\left(x_{0, i}, y_{0, r} \mid z_{0, p}\right) \in \Psi_{A}$. We intend to achieve its targets on the frontier of another cluster, say $B .\left(\begin{array}{c}x_{0, i, \vec{d}}^{\star B}, y_{0, r, \vec{d}}^{\star B} \\ x^{2}\end{array}\right) \in \mathbb{R}_{+}^{(m+s) \times 1}$ is the set of $m+s$ targets of council $l_{0}$ with respect to the frontier of that cluster, $\partial \Psi_{B}$, and $\vec{d}=\left(\overrightarrow{d_{X}}, \overrightarrow{d_{Y}}\right)$ is a directional vector controlling for the direction in which council $l_{0}$ is projected on $\partial \Psi_{*}$. Targets can be pre-defined or empirically determined. In the latter case, if DEA-like methods are employed, a linear combination of (at least, one) Pareto-efficient councils in $\partial \Psi_{B}$ is used to compute $\left(\begin{array}{c}\left.x_{0, i,}, \vec{d}, y_{0, r,}^{\star B}\right) \\ \star B\end{array}\right)$. Assessing these values assumes a prominent role in Ferreira and Marques' approach, as shown later. The next subsection describes how these targets can be computed through a very robust semi-parametric frontier-based method.

Assessing Targets. This paper adopts the bidirectional order- $\alpha$ (BDO- $\alpha)$ method, as introduced by Daraio and Simar [42]. Unlike standard DEA programs, BDO- $\alpha$ is less sensitive to outliers, extreme values, and the so-called curse of dimensionality, which results from many variables (either inputs or outputs) alongside a very low number of councils. It constructs an empirical nonconvex frontier by fixing the value of $1-\alpha$, which measures the probability of observing points above that frontier. These points are likely outliers or extreme values. Another advantage of this method (over its standard inputand output-oriented versions) is that it allows both input contraction and output expansion following the direction path defined by $\vec{d}=\left(\overrightarrow{d_{X}}, \overrightarrow{d_{Y}}\right)$. 
Hypothesis 1(H1) (Parameters). In this study, we select $\alpha=0.99$, i.e., assuming the existence of $1 \%$ of potential outliers. Furthermore, $\vec{d}=\left(\overrightarrow{d_{X}}, \overrightarrow{d_{Y}}\right)=(\overrightarrow{1}, \overrightarrow{1})$ is adopted. This choice of directional vector imposes that the input contraction and output expansion occur at the same rate.

Definition $1(\mathrm{BDO}-\alpha)$. Consider the transformation $\left(X_{i j_{A}}^{t}, Y_{r j_{A}}^{t}\right)=\left(\exp \left\{\frac{X_{i j_{A}}}{d_{X}}\right\}, \exp \left\{\frac{Y_{r j_{A}}}{d_{Y}}\right\}\right), j_{A}=$ $1, \ldots, N_{A}[42]$, and the equation:

$$
\mathfrak{F}^{A}\left(x_{0, i}, y_{0, r}\right)=\min \left\{\min _{i=1, \ldots, m}\left(\frac{x_{0, i}^{t}}{X_{i j_{A}}^{t}}\right), \min _{r=1, \ldots, S}\left(\frac{Y_{r j_{A}}^{t}}{y_{0, r}^{t}}\right)\right\},
$$

where $\mathbb{I}$ is the indicator function. Let us denote by $\mathfrak{F}_{(\mathcal{L})}^{x y}$ the $\mathcal{L}$ th order statistic of the $N_{A}$ councils, such that $\mathfrak{F}_{(1)}^{A} \leq \cdots \leq \mathfrak{F}_{(\mathcal{L})}^{A} \leq \cdots \leq \mathfrak{F}_{\left(N_{A}\right)}^{A}$. The radial order- $\alpha$ based distance of council $\left(\underset{0, i, \vec{d}}{x_{0, r}^{\star B}, y_{0, \vec{d}}^{\star B}}\right) \in \Psi_{A}$ with respect to $\partial \Psi_{A}$ is given as follows:

$$
\widehat{b}\left(x_{0, i}, y_{0, r}\right)=\log \left\{\begin{array}{lc}
\mathfrak{F}_{\left(\alpha n_{A}\right)}^{A} & \text { if } \alpha n_{A} \text { is an integer } \\
\mathfrak{F}_{\left(\left[\alpha n_{A}\right]+1\right)}^{A} & \text { otherwise }
\end{array}\right.
$$

Council $\left(x_{0, i}, y_{0, r}\right)$ is technically efficient regarding the $\alpha$-level frontier of $\Omega_{A}$, say $\partial \Omega_{A}^{(\alpha)}$, if $\widehat{b}=0$. It is technically inefficient if $\widehat{b}>0$ and super-efficient if $\widehat{b}<0$. Targets of council $\left(x_{0, i}, y_{0, r}\right)$ are, then, computed through Equation (3) [because of Hypothesis 1].

$$
\left\{\begin{array}{c}
x_{0, i, \vec{d}}^{\star A}=x_{0, i}-\widehat{b} \cdot \vec{d}=x_{0, i}-\overrightarrow{\vec{b}} \\
y_{0, r, \vec{d}}^{\star A}=y_{0, r}+\widehat{b} \cdot \vec{d}=y_{0, r}+\overrightarrow{\vec{b}}
\end{array},\right.
$$

where $\overrightarrow{\mathrm{d}}=\left(\overrightarrow{\mathrm{d}_{X}}, \overrightarrow{\mathrm{d}_{Y}}\right)=(\overrightarrow{1}, \overrightarrow{1})$. Mutatis mutandis, it is easy to obtain the targets of councils in A with respect to the frontier of $B$, and vice-versa.

Assessing the Relative Performance of Clusters. This paper uses the decomposition of the Total Factor Productivity (TFP), as proposed by Ferreira and Marques [38], to evaluate the relative performance of a set of four different clusters:

$$
\left\{\begin{array}{c}
A=\{\text { non-sustainable councils, ESIF III }\} \\
B=\{\text { sustainable councils, ESIF III }\} \\
C=\{\text { non-sustainable councils, NSRF }\} \\
D=\{\text { sustainable councils, NSRF }\}
\end{array}\right.
$$

For what follows, let us consider the Definition 2 of TFP between two councils. Definition 1 and Hypothesis 1 will be employed henceforth. From Definition 1 , we can state that $\operatorname{TFP}_{A B}\left(x_{1}, y_{1} ; x_{2}, y_{2}\right)>1$ when council 2 (read sustainable councils) is more productive than council 1 (read non-sustainable councils). Furthermore, this TFP formulation is decomposable into several terms, see Definitions 3 up to 6.

Definition 2 (TFP). The total factor productivity (TFP) between two councils, $\left(x_{1}, y_{1} \mid z_{1}\right) \in \Psi_{A}$ and $\left(x_{2}, y_{2} \mid z_{2}\right) \in \Psi_{B}$ is defined by $\operatorname{TFP}\left(x_{1}, y_{1} ; x_{2}, y_{2}\right)=\frac{\mathcal{M}\left(y_{2}\right)}{\mathcal{M}\left(y_{1}\right)} / \frac{\mathcal{L}\left(x_{2}\right)}{\mathcal{L}\left(x_{1}\right)}$, with $\mathcal{M}: \mathbb{R}^{s} \rightarrow \mathbb{R}$ and $\mathcal{L}: \mathbb{R}^{m} \rightarrow \mathbb{R}$.

Hypothesis 2(H2) (TFP). If both $\mathcal{M}$ and $\mathcal{L}$ functions are the geometric mean of their own arguments (vectors), then the previous measure of TFP is multiplicatively complete [25], i.e., it confirms the axioms of positivity, 
continuity, monotonicity, homogeneity, identity, commensurability, and reversal property. The TFP is then given by the following equation [43]:

$$
\operatorname{TFP}\left(x_{1}, y_{1} ; x_{2}, y_{2}\right)=\frac{\mathcal{M}\left(y_{2}\right)}{\mathcal{M}\left(y_{1}\right)} / \frac{\mathcal{L}\left(x_{2}\right)}{\mathcal{L}\left(x_{1}\right)}=\left(\prod_{r=1}^{s} \frac{y_{2, r}}{y_{1, r}}\right)^{\frac{1}{s}} /\left(\prod_{i=1}^{m} \frac{x_{2, i}}{x_{1, i}}\right)^{\frac{1}{m}} .
$$

Now, let us define a function, $\wp_{\ell}(\vec{v})$, which aggregates the values of the $\ell$-sized vector $\vec{v}$. If the vector $\vec{v}$ is, for instance, the ith vector of inputs targets of all the $N_{A}$ councils from $\Psi_{A}$ with respect to $\partial \Psi_{A}$, then its aggregation is simply $\wp_{N_{A}}\left(\begin{array}{c}x^{\star A} \\ j_{A}, i, \vec{d}\end{array}\right)$. Suppose that $\wp_{\ell}$ is the geometric mean. Then, $\wp_{N_{A}}\left(\begin{array}{c}x_{j_{A}, i, \vec{d}}^{\star A} \\ j_{A}\end{array}\right)=$

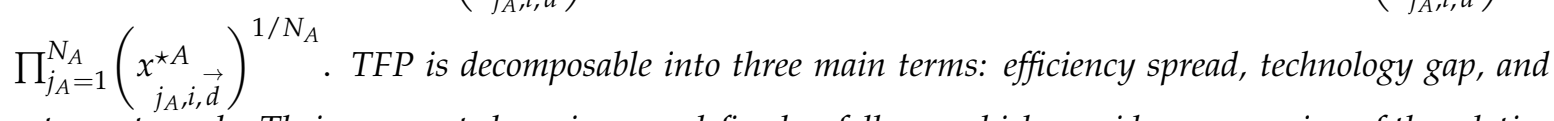
returns-to-scale. Their aggregated versions are defined as follows, which provides an overview of the relative performance of clusters.

Definition 3 (Efficiency spread, ES). Let us consider two directional vectors, $\vec{d}_{I}=(\overrightarrow{1}, \overrightarrow{1})$ and $\overrightarrow{d_{O}}=(\varepsilon \overrightarrow{1}, \overrightarrow{1})$, where $\varepsilon$ is a positive non-Archimedean number (as small as possible, say $\varepsilon \sim 10^{-10}$ ). Using these vectors, we can employ Equations (1)-(3) for targets assessment. In view of that, Equation (5) is a measure of the efficiency spread of the two clusters. Particularly, the technical efficiency of councils from cluster $B$ is, on average, higher than the one of councils from $A$ (with respect to their own frontier) if and only if $E S_{A B}>1$. No technical efficiency differences are expected whenever $E S_{A B}=1$.

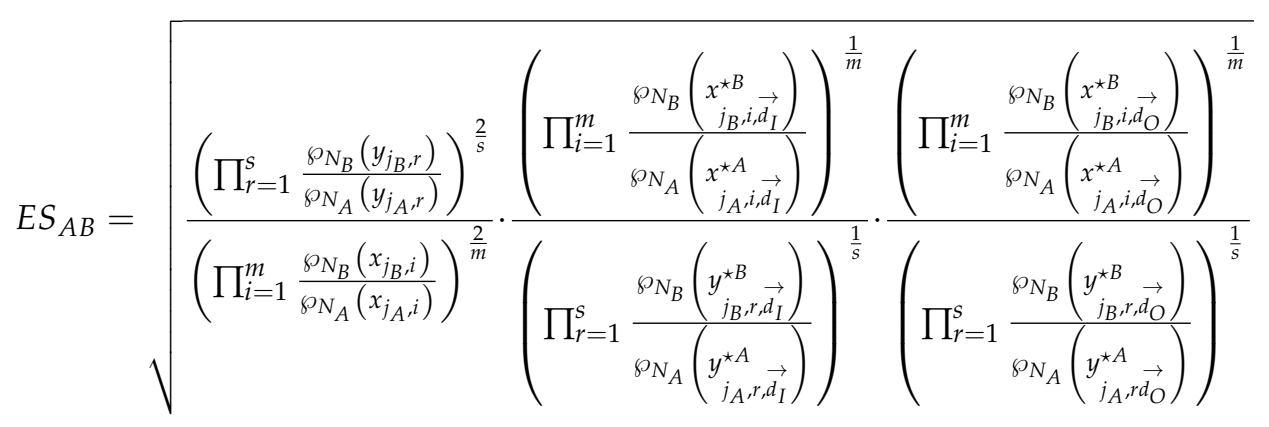

Definition 4. (Technological gap, TG). There is a technological gap (TG) between two technologies, $\partial \Psi_{A}$ and $\partial \Psi_{B}$, if one of them can produce more outputs with fewer resources than the other one. Considering the same directional vectors as in Definition 3, $\Psi_{B}$ is more productive than $\Psi_{A}$ if its benchmarks consume fewer resources than the ones in $\partial \Psi_{A}$, i.e., $R P_{A B}>1$, and/or those benchmarks produce more goods/services than their counterparts from $\Psi_{A}$, i.e., $G P_{A B}>1$. Additionally, $T G_{A B}=R P_{A B} \cdot G P_{A B}$. Thus, $T G_{A B}>1$ when $\partial \Psi_{B}$ is more productive than $\partial \Psi_{A}$, being:

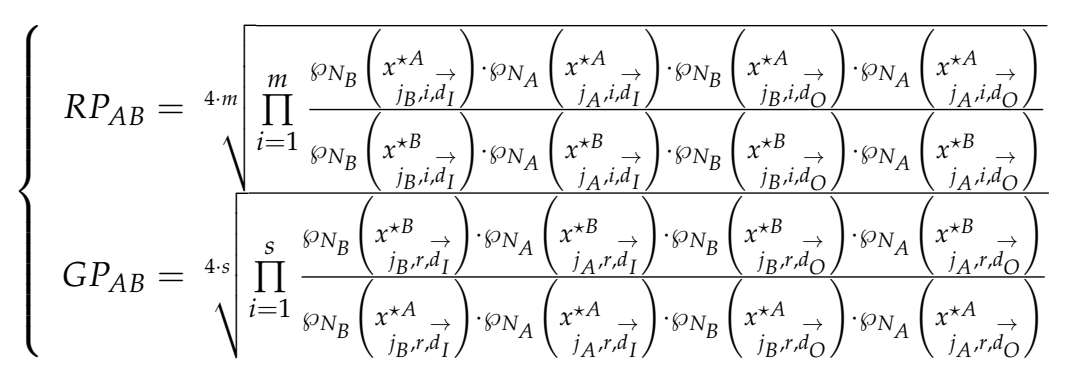


Definition 5 (Returns-to-scale, RTS). The returns-to-scale (RTS) index measures how close councils are from their own most productive scale size (MPSS), when compared to other councils from another cluster. Councils from $B$ are closer to their own MPSS than councils in $A$ if $R T S_{A B}>1$ and:

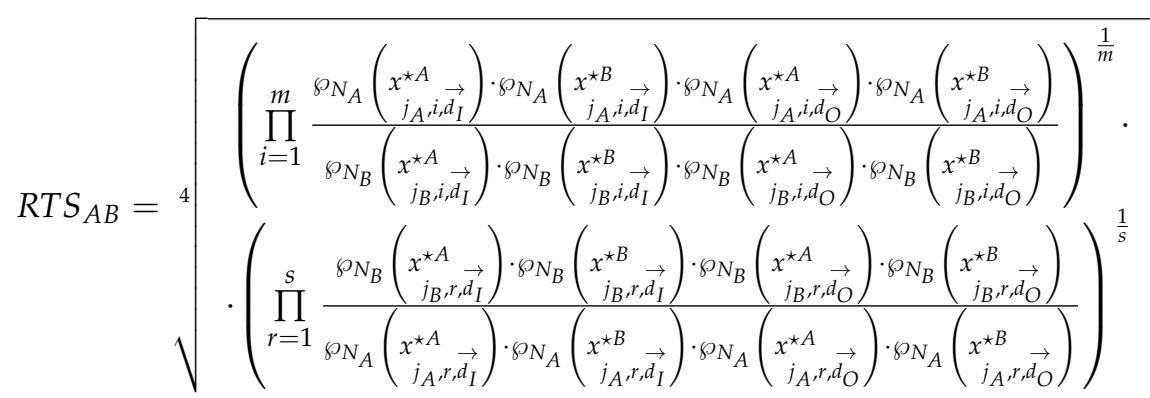

Hypothesis 3(H3) (Aggregating function). This paper adopts the geometric mean as the aggregating function, i.e., $\wp_{\ell}(\vec{v})=\prod_{k=1}^{\ell} v_{k}^{1 / \ell}$.

Definition 6 (HMI). Based on Hypothesis 3, the HMI [44] is a true measure of TFP, can be computed by means of Equation (4), and it is multiplicatively decomposable into the terms $E S_{A B}, R P_{A B}, G P_{A B}$, and $R T S_{A B}$ [38]. In other words, the product of Equations (5)-(7) returns the aggregated version of Equation (1).

\section{Empirical Evidence on Impact of EU Programs on Portuguese Councils}

\subsection{Portuguese Local Government}

Portuguese local government is composed of administrative regions, local councils, and civil parishes, with local authorities responsible for delivering local public services to residents. Council responsibilities are regulated (Law 75/2013 of 12 September 2013) and are diverse: rural and urban infrastructure, energy, transport and communication, education, local assets, culture and science, leisure and sports, health, social welfare, housing, civil protection, water supply, wastewater and urban waste, consumer protection, development promotion, planning, local police and, finally, intergovernmental relations [45]. Councils can cooperate with each other through various institutional arrangements and are free to choose governance structures for local public service production and provision [46].

As we can see from Figure 3, most of the Portuguese councils are small (185) and medium size (99) in terms of population and thus size may be an important determinant of council administration and technical capacity. The average size is 34,500 inhabitants-aligned with the European Union average—and councils are located unevenly by region [4].

Table 3 presents weighting of local functions in Portugal and EU average. Most of municipal expenditure is spent on General Functions (36\%), Other (26\%), and Economic Activity (22\%), as opposed to EU Average at $24 \%, 15 \%$, and $12 \%$, respectively.

Table 3. Weight of local functions in Portugal relative to European Union (EU) average.

\begin{tabular}{ccc}
\hline & Expenditure by Function \\
\hline & Portugal (\%) & EU Average (\%) \\
\hline Economic activity & 22 & 12 \\
Education & 9 & 23 \\
Health & 4 & 11 \\
Social protection & 3 & 15 \\
General functions & 36 & 24 \\
Other & 26 & 15 \\
\hline
\end{tabular}




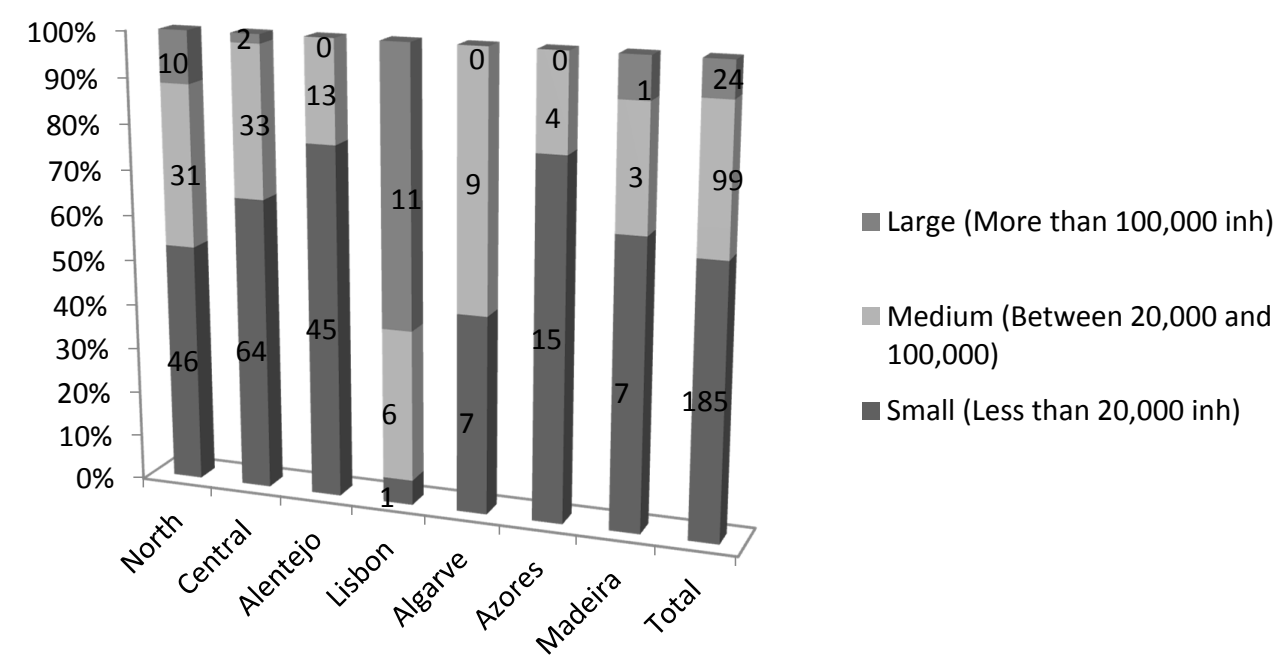

Figure 3. Portuguese councils' size by population and region.

\subsection{Does High Sustainability Means High EU Investments Performance?}

Our main hypothesis holds that the impact of ESIF, ESIF III (2000-2006), and NSRF (2007-2013) on key performance and sustainability indicators for Portuguese sustainable councils and non-sustainable councils was varied. The research period was between 2000 and 2014 (i.e., 15 years) and covered the most sustainable and the least sustainable Portuguese councils.

Council investment and funds data for each year of the research period were collected from the National Agency for Development and Cohesion (NADC), which is the entity responsible for the management and evaluation of the Portuguese execution of EU cohesion funds. Moreover, council key performance and sustainability indicators data for each year of the research period were collected from the National Institute of Statistics.

The analysis considered the variables presented in Table 4, in view of the type of investment/funds and the three main thematic objectives of EU programs: competitiveness factors, territory development, and human potential.

Clusters. This paper used the following clusters:

\section{A-Non-sustainable councils, ESIF III \\ B-Sustainable councils, ESIF III \\ C-Non-sustainable councils, NSRF \\ D-Sustainable councils, NSRF}

The clusters result from the application of the CSI to the 308 Portuguese councils and the specific councils that integrate each cluster-which are provided in Tables A2 and A3 in the Appendix A-distinguishing between sustainable councils (best 10\% performers) and non-sustainable councils (worst $10 \%$ performers).

Research hypotheses. We considered the following research hypotheses:

$\mathbf{H}_{1}$ : Sustainable councils are more efficient than non-sustainable councils.

$\mathbf{H}_{2}$ : Sustainable councils are more productive than non-sustainable councils.

$\mathbf{H}_{3}$ : Worst/best performers in NSRF are more efficient than the worst/best ones under ESIF III.

$\mathbf{H}_{4}$ : Worst/best performers in NSRF are more productive than the worst/best ones under ESIF III.

$\mathbf{H}_{5}$ : Worst/best performers in NSRF are more efficient than the best/worst ones under ESIF III.

$\mathbf{H}_{6}$ : Worst/best performers in NSRF are more productive than the best/worst ones under ESIF III.

By testing differentiated efficiency and productivity, these hypotheses' cover councils' higher/lower sustainability level is based on four specific broad dimensions-governance, government 
effectiveness, economic and social development, and financial sustainability-as well as including the ESIF III and NSRF characteristics considered earlier. This allows for differential council behaviour in each period.

Table 4. Variables description and references (2010_ESIF III and 2015-NSRF).

\begin{tabular}{|c|c|c|}
\hline Variable & Description & Units \\
\hline $\begin{array}{l}\text { Input-Investment per } \\
\text { inhabitant [47] }\end{array}$ & $\begin{array}{l}\text { EU investments allocated and applied in each } \\
\text { council divided by number of residents. }\end{array}$ & $1000 €$ \\
\hline $\begin{array}{l}\text { Input-Funds per } \\
\text { inhabitant [47] }\end{array}$ & $\begin{array}{l}\text { EU funds allocated and applied in each } \\
\text { council divided by number of residents. }\end{array}$ & $1000 €$ \\
\hline $\begin{array}{l}\text { Output-Purchasing power } \\
\text { per capita PPP [12,48-50] }\end{array}$ & $\begin{array}{l}\text { This composite indicator is intended to } \\
\text { translate the purchasing power in per capita } \\
\text { terms. }\end{array}$ & $\begin{array}{l}\text { It is an index number with the value } \\
100 \text { in the country average, which } \\
\text { compares the purchasing power, in } \\
\text { per capita terms, in different councils } \\
\text { or regions. }\end{array}$ \\
\hline $\begin{array}{l}\text { Output-Companies gross } \\
\text { value added per capita } \\
{[18-20,51]}\end{array}$ & $\begin{array}{l}\text { The company gross added value (GAV) is the } \\
\text { wealth per resident generated in the } \\
\text { production, discounting the value of goods } \\
\text { and services consumed to achieve it, for } \\
\text { example, the raw materials. The values are } \\
\text { gross when the consumption of fixed capital } \\
\text { is not assumed. }\end{array}$ & $1000 €$ \\
\hline $\begin{array}{l}\text { Output—(Education) high } \\
\text { school conclusion rate } \\
{[14,52,53]}\end{array}$ & $\begin{array}{l}\text { Success rate meaning the number of students } \\
\text { that concluded high school divided by the } \\
\text { total number of students. }\end{array}$ & $\%$ \\
\hline $\begin{array}{l}\text { Output-(Health) doctors } \\
\text { per } 1000 \text { inhabitants }[14,54]\end{array}$ & $\begin{array}{l}\text { Number of doctors divided by a thousand } \\
\text { residents. }\end{array}$ & No \\
\hline $\begin{array}{l}\text { Output-(Indebtedness) } \\
\text { debt service ratio }[55,56]\end{array}$ & $\begin{array}{l}\text { Sum of interest paid plus capital debt } \\
\text { amortization divided by total expenses. }\end{array}$ & $\%$ \\
\hline
\end{tabular}

\subsection{Results}

Table 5 is provided to assist readers in the following discussion of the study findings. Table 6 provides the comparison between sustainable and non-sustainable councils covering both EU Programs (ESIF III and NSRF). From these results, we can observe that sustainable councils are indeed more efficient than councils that have been considered as non-sustainable on the CSI. Given this outcome, Hypothesis $\mathrm{H} 1$ cannot be rejected at the $95 \%$ confidence level. It is important to note that differences in terms of technical efficiency are clearer in ESIF III than in the NSRF. Nevertheless, in none of these scenarios were productivity gaps statistically meaningful, as predicted by the Hicks-Moorsteen index, which is a measure of total factor productivity (see Definition 6). In other words, Hypothesis $\mathrm{H} 2$ is rejected. This results from the non-existence of significant technology gaps between clusters. In other words, benchmarks from both worst and best council clusters (in terms of the CSI-related sustainability) can produce similar amounts of outputs accounting for comparable levels of inputs. As to the returns to scale, the best councils with respect to sustainability seem to be closer to their optimal (most productive) scale size than the worst ones under the ESIF III program. It is no longer true under NSRF that both best and worst councils share similar positions regarding their own most productive scale size. It seems there was a convergence of councils through time regarding their scale efficiency. 
Table 5. Definitions of the productivity indexes.

\begin{tabular}{cccc}
\hline Index & \multicolumn{1}{c}{$<$ 1 } & =1 & $>\mathbf{1}$ \\
\hline$E S_{A B}$ & $\begin{array}{c}\text { Councils of cluster A have a } \\
\text { higher average technical } \\
\text { efficiency than councils of B }\end{array}$ & $\begin{array}{c}\text { Councils of both clusters A and } \\
\text { B have similar technical } \\
\text { efficiency levels }\end{array}$ & $\begin{array}{c}\text { Councils of cluster A have a } \\
\text { lower average technical } \\
\text { efficiency than councils of B. }\end{array}$ \\
\hline$R P_{A B}$ & $\begin{array}{c}\text { Benchmarks of cluster A } \\
\text { consume fewer resources than } \\
\text { benchmarks of B }\end{array}$ & $\begin{array}{c}\text { The consumption profile of } \\
\text { benchmarks of both clusters is } \\
\text { similar }\end{array}$ & $\begin{array}{c}\text { Benchmarks of cluster A } \\
\text { consume more resources than } \\
\text { benchmarks of B. }\end{array}$ \\
\hline$G P_{A B}$ & $\begin{array}{c}\text { Benchmarks of cluster A } \\
\text { deliver more services than } \\
\text { benchmarks of B }\end{array}$ & $\begin{array}{c}\text { The production profile of } \\
\text { benchmarks of both clusters is } \\
\text { similar }\end{array}$ & $\begin{array}{c}\text { Benchmarks of cluster A } \\
\text { delivery less services than } \\
\text { benchmarks of B. }\end{array}$ \\
\hline$T G_{A B}$ & $\begin{array}{c}\text { Overall, the productivity of A } \\
\text { is higher than the productivity } \\
\text { of B }\end{array}$ & $\begin{array}{c}\text { Overall, the productivity levels } \\
\text { of A and B are identical }\end{array}$ & $\begin{array}{c}\text { Overall, the productivity of A is } \\
\text { lower than the productivity of B. }\end{array}$ \\
\hline$R T S_{A B}$ & $\begin{array}{c}\text { Councils of cluster A are closer } \\
\text { to their optimal scale than } \\
\text { councils of B }\end{array}$ & $\begin{array}{c}\text { Councils of clusters A and B are } \\
\text { "at the same distance" to their } \\
\text { optimal scale }\end{array}$ & $\begin{array}{c}\text { Councils of cluster B are closer } \\
\text { to their optimal scale than } \\
\text { councils of A. }\end{array}$ \\
\hline$H M I_{A B}$ & Overall, total factor & $\begin{array}{c}\text { Overall, both clusters share } \\
\text { identical total factor } \\
\text { productivity levels }\end{array}$ & $\begin{array}{c}\text { Overall, total factor productivity } \\
\text { of B is higher than A }\end{array}$ \\
\hline
\end{tabular}

Table 7 compares the efficiency and productivity results for the ESIF III and NSRF clusters. The transition from ESIF III to NSRF has promoted a slight decrease (2-3\%) of technical efficiency in both the worst and best councils. This can be seen in the confidence intervals of ES ${ }^{* *}$ in the second and the fifth columns of Table 5. The interval upper bound is lower than 1; thus, clusters A and B exhibit lower efficiency spreads (higher consistency) than C and D, respectively. Put differently, Hypothesis $\mathrm{H} 3$ is rejected at the $95 \%$ confidence level. This transition has also seen a poorer utilization of resources for comparable levels of produced goods/services. According to the values of both $\mathrm{RP}_{\mathrm{AC}}$ and $\mathrm{RP} \mathrm{P}_{\mathrm{BD}}$, on average, benchmarks from NSRF-based clusters consume about 4-6\% more resources than their counterparts in ESIF III-based groups, for the same amounts of outputs. Since no differences on the output-based index, $\mathrm{GP}_{\mathrm{AC}}$ and $\mathrm{GP}_{\mathrm{BD}}$, have been detected (i.e., the corresponding confidence intervals), no technological gaps, $\mathrm{TG}_{\mathrm{AC}}$ and $\mathrm{TG}_{\mathrm{BD}}$, were detected. However, there was a substantial withdrawal from the optimal scale due to the transition of ESIF III-NSRF, as observed by the reduced values of RTS $_{\mathrm{AC}}$ and RTS $\mathrm{BD}$. This means that the overall productivity of both best and worst councils concerning sustainability has decreased over time $\left(\mathrm{HMI}_{\mathrm{AC}}, \mathrm{HMI}_{\mathrm{BD}}<1\right)$. Since these councils have become less productive, Hypothesis $\mathrm{H} 4$ is rejected at the $95 \%$ level. Similar and consistent conclusions arise by comparing cluster A with D and B with C. On the one hand, the best councils in NSRF are considerably less productive than the worst councils in ESIF III. On the other hand, the best councils in ESIF III are more productive than the worst councils in the NSRF, which is an expected outcome and discards Hypothesis H6. Accordingly, a circular condition can be observed, in line with both Hypothesis 2 and Definition 6. This condition is illustrated in Figure 4, which encompasses the results shown in Tables 6 and 7, highlighting in both periods which council group (sustainable and non-sustainable) is more productive. 
Table 6. Comparison between sustainable and non-sustainable councils, in both ESIF III and NSRF scenarios. (Expected values, 95\% confidence intervals, and comments).

\begin{tabular}{|c|c|c|c|}
\hline & Index & Results & Comments \\
\hline \multirow{6}{*}{ 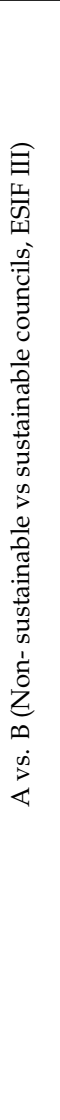 } & $E S_{A B}$ (efficiency spread) & $\begin{array}{l}1.0327 * \\
{[1.0081 ; 1.2142]_{95 \%}}\end{array}$ & $\begin{array}{l}\text { The technical efficiency of sustainable councils (ESIF } \\
\text { III) is higher than the efficiency of non-sustainable } \\
\text { ones. This is because the former are closer to their } \\
\text { efficient frontier than the latter. On average, the } \\
\text { efficiency of sustainable councils is } \sim 3 \% \text { higher than } \\
\text { that of non-sustainable municipalities. Such a gap can } \\
\text { reach } ~ 21 \% \text {. Differences are statistically significant } \\
\text { since the } 95 \% \text { confidence interval's lower bound is } \\
\text { larger than } 1 \text {. }\end{array}$ \\
\hline & $\begin{array}{l}R P_{A B} \text { (resources } \\
\text { productivity) }\end{array}$ & $\begin{array}{l}1.0580 * \\
{[1.0368 ; 1.0504]_{95 \%}}\end{array}$ & $\begin{array}{l}\text { Sustainable and technically efficient councils (ESIF III) } \\
\text { consume } 4-5 \% \text { less resources than benchmarks in the } \\
\text { non-sustainable councils' cluster, for equivalent levels } \\
\text { of produced goods / services. Differences are } \\
\text { statistically significant at the } 95 \% \text { confidence level. }\end{array}$ \\
\hline & $\begin{array}{l}G P_{A B} \text { (outputs } \\
\text { productivity) }\end{array}$ & $\begin{array}{l}0.8200 * * \\
{[0.7846 ; 1.1298]_{95 \%}}\end{array}$ & $\begin{array}{l}\text { Non-sustainable and technically efficient councils } \\
\text { (ESIF III) produce, on average, } 18 \% \text { more goods } \\
\text { and/or services than the best practices in B. } \\
\text { Nevertheless, differences are not meaningful from the } \\
\text { statistical point of view. }\end{array}$ \\
\hline & $T G_{A B}$ (technology gap) & $\begin{array}{l}0.8199 * * \\
{[0.7813 ; 1.1013]_{95 \%}}\end{array}$ & $\begin{array}{l}\text { Both technologies are similar because }\{1\} \in[0.7813 \text {; } \\
1.1013]_{95 \%} \text {. That is, benchmarks from A and B produce } \\
\text { similar amounts of outputs with equivalent levels of } \\
\text { resources. This suggests that both groups of councils } \\
\text { are equally productive. }\end{array}$ \\
\hline & $R T S_{A B}$ (returns to scale) & $\begin{array}{l}1.6038 * \\
{[1.0910 ; 5.3457]_{95 \%}}\end{array}$ & $\begin{array}{l}\text { Sustainable councils (ESIF III) are closer to their MPSS } \\
\text { than non-sustainable councils. Differences are } \\
\text { significant at the } 95 \% \text { confidence level. }\end{array}$ \\
\hline & $\begin{array}{l}H M I_{A B} \text { (total factor } \\
\text { productivity) }\end{array}$ & $\begin{array}{l}0.9625 * * \\
{[0.8860 ; 3.7402]_{95 \%}}\end{array}$ & $\begin{array}{l}\text { Although on average the productivity (TFP) of A is } \\
\text { about } 4 \% \text { higher than the one in B, there is no } \\
\text { statistical evidence of a considerable productivity gap } \\
\text { between these two technologies. That is, both } \\
\text { sustainable and non-sustainable councils in the ESIF III } \\
\text { program can reach equivalent productivity levels. }\end{array}$ \\
\hline \multirow{6}{*}{ 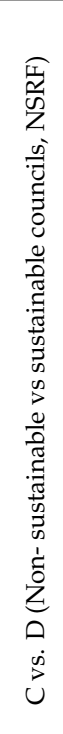 } & $E S_{C D}$ (efficiency spread) & $\begin{array}{l}1.0096 * \\
{[1.0032 ; 1.1567]_{95 \%}}\end{array}$ & $\begin{array}{l}\text { Sustainable councils (NSRF) are, in general, more } \\
\text { efficient than non-sustainable units. Gaps in efficiency } \\
\text { spread can hit } 15 \% \text {. Gaps are significant at the } 95 \% \\
\text { level. }\end{array}$ \\
\hline & $\begin{array}{l}R P_{C D} \text { (resources } \\
\text { productivity) }\end{array}$ & $\begin{array}{l}0.9782 * \\
{[0.9038 ; 0.9792]_{95 \%}}\end{array}$ & $\begin{array}{l}\text { Keeping the outputs unchanged, the efficient } \\
\text { technology of cluster C consumes } 2-10 \% \text { less resources } \\
\text { than the one of cluster D. }\end{array}$ \\
\hline & $\begin{array}{l}G P_{C D} \text { (outputs } \\
\text { productivity) }\end{array}$ & $\begin{array}{l}0.8446 \text { ** } \\
{[0.8452 ; 1.1199]_{95 \%}}\end{array}$ & $\begin{array}{l}\text { For equivalent resources consumption's levels, } \\
\text { benchmarks from cluster C can produce } 15 \% \text { more } \\
\text { outputs than cluster D. Yet, differences are not } \\
\text { statistically meaningful. }\end{array}$ \\
\hline & $T G_{C D}$ (technology gap) & $\begin{array}{l}0.8199 * * \\
{[0.8248 ; 1.0844]_{95 \%}}\end{array}$ & $\begin{array}{l}\text { No significant technological gap has been found } \\
\text { between these two clusters, thus they are equally } \\
\text { productive. }\end{array}$ \\
\hline & $R T S_{C D}$ (returns to scale) & $\begin{array}{l}1.4561 * * \\
{[0.3040 ; 1.8396]_{95 \%}}\end{array}$ & $\begin{array}{l}\text { Sustainable and non-sustainable councils exhibit } \\
\text { comparable scale efficiencies. That is, they are at the } \\
\text { same distance (on average) to their own MPSS. }\end{array}$ \\
\hline & $\begin{array}{l}H M I_{C D} \text { (total factor } \\
\text { productivity) }\end{array}$ & $\begin{array}{l}0.9936 * * \\
{[0.2010 ; 4.3975]_{95 \%}}\end{array}$ & $\begin{array}{l}\text { No statistically significant differences between these } \\
\text { two clusters were found in terms of productivity. The } \\
\text { expected value of HMI is close to 1, a value belonging } \\
\text { to the } 95 \% \text { confidence interval. }\end{array}$ \\
\hline
\end{tabular}

* The index is statistically different from 1 , at the $5 \%$ significance level (or lower); ${ }^{* *}$ The index is not statistically different from 1 , at the $5 \%$ significance level (or lower). 
Table 7. ESIF III vs. NSRF comparison results (Expected values and 95\% confidence intervals).

\begin{tabular}{ccccc}
\hline Index & $\boldsymbol{A}$ vs. $\boldsymbol{C}$ & $\boldsymbol{A}$ vs. $\boldsymbol{D}$ & $\boldsymbol{B}$ vs. $\boldsymbol{C}$ & $\boldsymbol{B}$ vs. $\boldsymbol{D}$ \\
\hline \multirow{2}{*}{$E S_{* *}$} & 0.9765 & 0.9958 & 0.9534 & 0.9756 \\
& {$[0.9491 ; 0.9932]_{95 \%}$} & {$[0.9963 ; 1.1383]_{95 \%}$} & {$[0.8082 ; 0.9852]_{95 \%}$} & {$[0.9575 ; 0.9884]_{95 \%}$} \\
\hline \multirow{2}{*}{$R P_{* *}$} & 0.9566 & 1.0453 & 1.0027 & 0.9405 \\
& {$[0.7295 ; 0.9597]_{95 \%}$} & {$[1.0049 ; 1.0428]_{95 \%}$} & {$[0.9059 ; 1.0061]_{95 \%}$} & {$[0.9351 ; 0.9606]_{95 \%}$} \\
\hline \multirow{2}{*}{$G P_{* *}$} & 1.1350 & 0.6800 & 1.0924 & 0.9568 \\
& {$[0.9466 ; 1.4419]_{95 \%}$} & {$[0.6033 ; 0.9370]_{95 \%}$} & {$[0.7021 ; 1.2173]_{95 \%}$} & {$[0.9221 ; 1.1338]_{95 \%}$} \\
\hline \multirow{2}{*}{$T G_{* *}$} & 1.0523 & 0.7454 & 1.1947 & 0.9654 \\
& {$[0.9101 ; 1.2811]_{95 \%}$} & {$[0.6555 ; 0.9746]_{95 \%}$} & {$[0.7188 ; 1.0464]_{95 \%}$} & {$[0.9282 ; 1.0582]_{95 \%}$} \\
\hline \multirow{2}{*}{$R T S_{* *}$} & 0.5698 & 0.8257 & 0.4465 & 0.6825 \\
& {$[0.5248 ; 0.6637]_{95 \%}$} & {$[0.2849 ; 4.0920]_{95 \%}$} & {$[0.3645 ; 0.7393]_{95 \%}$} & {$[0.2558 ; 0.7118]_{95 \%}$} \\
\hline \multirow{2}{*}{$H M I_{* *}$} & 0.5816 & 0.5199 & 0.5429 & 0.5802 \\
& {$[0.5635 ; 0.6156]_{95 \%}$} & {$[0.1348 ; 2.4906]_{95 \%}$} & {$[0.0832 ; 0.8757]_{95 \%}$} & {$[0.1922 ; 0.6482]_{95 \%}$} \\
\hline
\end{tabular}

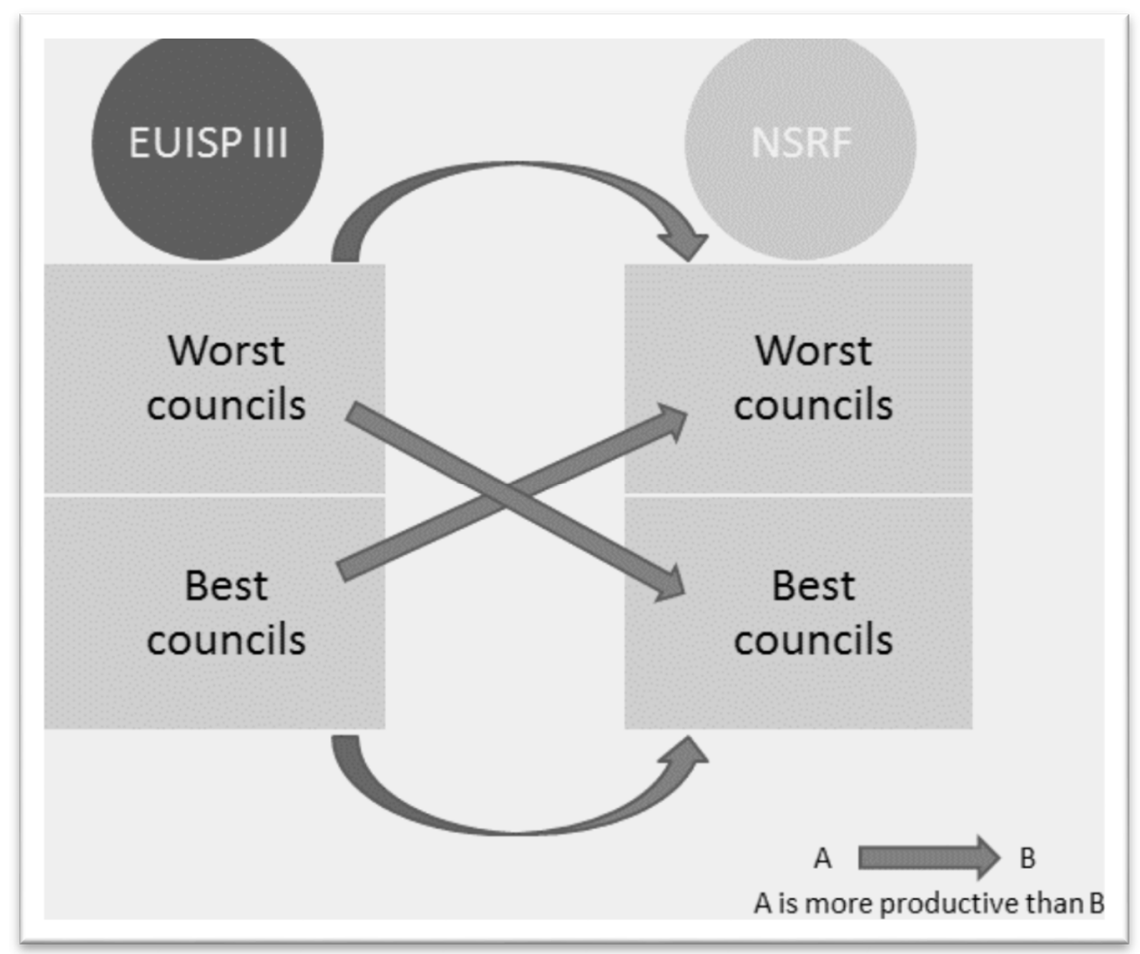

Figure 4. Productivity relationships between councils' groups.

\section{Concluding Remarks}

Established in 1986, the ESIF played a crucial role in the economic and social development of Portugal, especially on the finance provided at the local level. This paper has focused on the differential impact of EU investments and funds programs by applying the CSI, a new local government evaluation model developed by Caldas et al. [23].

The empirical analysis conducted in this paper allows us to draw four major conclusions. In the first place, we found that sustainable councils are more efficient due to sound levels of governance, government effectiveness, economic and social development, and/or financial sustainability. However, they are not more productive than councils which were determined to be non-sustainable under the CSI. In sum, for both EU programs, the difference in investment impact was not significant regardless of whether a council exhibited higher or lower levels of sustainability. 
Secondly, the importance of EU programs to the structural adjustment of the Portuguese economy is recognised and continuity of EU cohesion policies seems imperative to guarantee sustainable development.

Finally, we found that both efficiency and productivity are higher on ESIF III (2000-2006) than under NSRF (2007-2013)—for sustainable and non-sustainable councils alike-because of the stronger effects of ESIF III on the economic and social circumstances of residents, including increased competitiveness, spatial development, and the human potential of individual councils and specific regions.

From a policy perspective, our findings suggest that ESIF should continue fostering economic and social development at the local level regardless of council size or regional location since overall development will flow from this economic and social structural adjustment strategy. More generally, we conclude that ESIF strategies have made a positive contribution to Portuguese development contribution whilst respecting the principle of subsidiarity [5].

Further empirical investigation is required on the specific investment impact under the ESIF using different output indicators. In addition, the CSI could be fruitfully applied to council performance and sustainability throughout Europe. Importantly, a new CSI including environmental dimensions should be constructed, a benchmarking exercise should be carried out, and its outcomes should be compared with the ones achieved in the current research.

Acknowledgments: This work was financially supported by UNERA scholarship and by the Portuguese Foundation for Science and Technology (FCT) and the European Social Fund: SFRH/BD/113038/2015. Furthermore, we would like to thank to three anonymous referees who kindly and significantly have improved the paper quality, clarity, and structure, due to their beneficial comments. Any errors are our own responsibility.

Author Contributions: All authors have contributed equally to this paper development. Paulo Caldas collected data and wrote Section 1, Section 2, Section 3, and Section 5; Diogo Cunha Ferreira analyzed data, and performed the experiments, and wrote Sections 4 and 5; Paulo Caldas and Diogo Cunha Ferreira wrote Section 5; Brian Dollery and Rui Cunha Marques both designed the experiments (case study), reviewed, and made substantial criticisms and changes on the entire manuscript.

Conflicts of Interest: The authors declare no conflict of interest.

\section{Appendix A}

Please consider Tables A1 and A2. The former details the European structural and investment funds within the period 1986 and 2013. The latter presents the $10 \%$ best and $10 \%$ worst performers (councils) according to the CSI Sustainability Index. 
Table A1. European Structural and Investment Funds (1986-2013).

\begin{tabular}{|c|c|c|c|c|c|}
\hline & $\begin{array}{l}\text { Previous Regulation 1986-1988 } \\
\text { (Exclusive Funding of Public } \\
\text { Infrastructures) }\end{array}$ & $\begin{array}{l}\text { European Structural and } \\
\text { Investment Funds I } \\
(1989-1993)\end{array}$ & $\begin{array}{c}\text { European Structural and } \\
\text { Investment Funds II (1994-1999) }\end{array}$ & $\begin{array}{c}\text { European Structural and } \\
\text { Investment Funds III (2000-2006) }\end{array}$ & $\begin{array}{l}\text { National Strategic Reference } \\
\text { Program-NSRF (2007-2013) }\end{array}$ \\
\hline Total Investment & 1185 million euros & 4600 million euros & 14,589 million euros & 20,528 million euros & 21,500 million euros \\
\hline $\begin{array}{l}\text { Programs-Strategic Axes } \\
\text { and Projects }\end{array}$ & $\begin{array}{l}\text { Four Specific Programs-National } \\
\text { Program of community interest of } \\
\text { incentives to productive activity; } \\
\text { specific program for } \\
\text { telecommunications (STAR) and } \\
\text { energy (VALOREN); integrated } \\
\text { operation of the northern } \\
\text { development Alentejo Region. }\end{array}$ & $\begin{array}{l}\text { Several territorial and } \\
\text { sectorial specific projects. }\end{array}$ & $\begin{array}{l}\text { Axes of intervention: qualify } \\
\text { human resources and employment; } \\
\text { strengthen the factors of } \\
\text { competitiveness of the economy; } \\
\text { promote the quality of life and } \\
\text { social cohesion; and strengthen the } \\
\text { regional economic base. There was } \\
\text { also a diversity of programs by } \\
\text { sector and region assigned } \\
\text { operational interventions. }\end{array}$ & $\begin{array}{l}\text { Four strategic Axes: raise the level } \\
\text { of qualification of the Portuguese, } \\
\text { promote the employment and } \\
\text { social cohesion (about } 24 \% \text { of the } \\
\text { public expenditure); change the } \\
\text { profile productive towards the } \\
\text { activities of the future ( } 20 \% \text { of } \\
\text { public expenditure); affirm the } \\
\text { value of the territory and of the geo } \\
\text { position of the economic country } \\
\text { (10\% of the public expenditure); } \\
\text { and promote the sustainable } \\
\text { development of the regions and the } \\
\text { national cohesion ( } 46 \% \text { of public } \\
\text { expenditure). }\end{array}$ & $\begin{array}{l}\text { Three Thematic } \\
\text { Programs-operational program of } \\
\text { territorial development OPTD; } \\
\text { operational program of human } \\
\text { potential OPHP; and the program } \\
\text { CFOP-competitiveness factors } \\
\text { operational Program. Seven } \\
\text { Regional Programs, corresponding } \\
\text { to each of the regions as part of the } \\
\text { mainland and Regions. }\end{array}$ \\
\hline Major Contributions & $\begin{array}{l}\text { Innovative principles of the } 1988 \\
\text { Reform: concentration (in a limited } \\
\text { number objectives and application } \\
\text { to regions whose development is } \\
\text { lagging behind), the additionality } \\
\text { (community expenditure } \\
\text { complemented by national } \\
\text { expenditure), the partnership } \\
\text { (involvement of all levels of } \\
\text { national and community } \\
\text { administration and social partners } \\
\text { in the preparation and } \\
\text { implementation of programs) and } \\
\text { programming (refusal of financing } \\
\text { of individual projects and their } \\
\text { pluri-annual programs and } \\
\text { pluri-sectorial framework and, } \\
\text { preferably, interregional). The word } \\
\text { evaluation appears for the first } \\
\text { time. }\end{array}$ & $\begin{array}{l}\text { Notwithstanding the } \\
\text { efforts, it was not possible } \\
\text { to efficiently mobilize and } \\
\text { achieve the corporate } \\
\text { sector, in terms of its } \\
\text { management and } \\
\text { competitiveness. }\end{array}$ & $\begin{array}{l}\text { It fulfilled the objectives of output } \\
\text { growth, the employment, real } \\
\text { convergence with the other } \\
\text { countries of the community, and of } \\
\text { convergence between internal } \\
\text { regions. High performance and } \\
\text { adaptation of the programs to the } \\
\text { operating context and social } \\
\text { evolution-the increasing } \\
\text { economic effectiveness of the } \\
\text { structural funds. }\end{array}$ & $\begin{array}{l}\text { Based on the National Plan for } \\
\text { Economic and Social Development, } \\
\text { the Program outlined the purlins of } \\
\text { the medium- and long-term } \\
\text { development of Portugal: Atlantic } \\
\text { economy border of Europe; } \\
\text { privilege of activities, } \\
\text { competitiveness factors and } \\
\text { technologies more structural } \\
\text { dynamic of the global economy; a } \\
\text { National Strategy for nature } \\
\text { conservation and biodiversity, } \\
\text { protection and enhancement of the } \\
\text { natural heritage, and enhancement } \\
\text { of solidarity and cohesion as } \\
\text { regards the social development } \\
\text { model. }\end{array}$ & $\begin{array}{l}\text { It surpassed the multiplicity of } \\
\text { existing sectorial programs in the } \\
\text { EU Investment and Funds Program } \\
\text { III and the fact that management } \\
\text { should be made through the } \\
\text { centralized level of Operational } \\
\text { Programs instead of being made, } \\
\text { as in the past, at the project level. }\end{array}$ \\
\hline
\end{tabular}

Source: Elaborated by the authors, based on EU Structural Funds Execution Reports. 
Table A2. CSI sustainability results (Top 10\% best performers).

\begin{tabular}{|c|c|c|c|c|c|c|c|c|c|c|c|c|}
\hline \multicolumn{13}{|c|}{ Sustainable Councils-Best $10 \%$ Performers } \\
\hline Regions & Size & Councils & $\begin{array}{c}\text { Global } \\
\text { Ranking }\end{array}$ & $\begin{array}{l}\text { Council } \\
\text { Position }\end{array}$ & $\begin{array}{l}\text { Governance } \\
\text { Ranking }\end{array}$ & $\begin{array}{l}\text { Council } \\
\text { Position }\end{array}$ & $\begin{array}{c}\text { Government } \\
\text { Effectiveness } \\
\text { Ranking }\end{array}$ & $\begin{array}{l}\text { Council } \\
\text { Position }\end{array}$ & $\begin{array}{c}\text { Economic and Social } \\
\text { Development } \\
\text { Ranking }\end{array}$ & $\begin{array}{l}\text { Council } \\
\text { Position }\end{array}$ & $\begin{array}{l}\text { Financial } \\
\text { Sustainability } \\
\text { Ranking }\end{array}$ & $\begin{array}{l}\text { Council } \\
\text { Position }\end{array}$ \\
\hline Lisbon & $\mathrm{L}$ & Lisboa & 235.86 & 1 & 5.41 & 173 & 29.54 & 93 & 179.50 & 1 & 21.41 & 241 \\
\hline Lisbon & $\mathrm{L}$ & Oeiras & 221.98 & 2 & 6.06 & 146 & 42.80 & 47 & 134.34 & 2 & 38.78 & 117 \\
\hline Algarve & $\mathrm{M}$ & Loulé & 177.85 & 3 & 6.61 & 126 & 56.64 & 25 & 20.00 & 62 & 94.60 & 8 \\
\hline North & $\mathrm{M}$ & São João da Madeira & 171.22 & 4 & 0.64 & 301 & 56.16 & 26 & 69.77 & 4 & 44.64 & 82 \\
\hline Azores & $\mathrm{S}$ & Corvo & 166.12 & 5 & 1.30 & 293 & 21.96 & 134 & -8.00 & 244 & 150.85 & 1 \\
\hline Central & $\mathrm{M}$ & Entroncamento & 162.71 & 6 & 6.47 & 134 & 97.23 & 2 & 24.22 & 39 & 34.80 & 148 \\
\hline Central & $\mathrm{M}$ & Águeda & 160.14 & 7 & 8.69 & 56 & 86.24 & 5 & 26.82 & 31 & 38.38 & 119 \\
\hline Central & $\mathrm{s}$ & Constância & 158.64 & 8 & 8.36 & 73 & 85.46 & 7 & 23.85 & 40 & 40.96 & 98 \\
\hline Alentejo & $\mathrm{s}$ & Sines & 150.09 & 9 & 6.34 & 139 & 32.75 & 82 & 65.93 & 5 & 45.07 & 76 \\
\hline Central & $\mathrm{s}$ & Figueira de Castelo Rodrigo & 145.27 & 10 & 6.57 & 130 & 9.12 & 212 & -0.70 & 196 & 130.28 & 2 \\
\hline Lisbon & $\mathrm{L}$ & Vila Franca de Xira & 141.74 & 11 & 2.82 & 260 & 85.85 & 6 & 25.58 & 34 & 27.49 & 199 \\
\hline North & $\mathrm{L}$ & Maia & 140.45 & 12 & 4.70 & 206 & 70.91 & 14 & 36.85 & 14 & 27.98 & 192 \\
\hline North & $\mathrm{M}$ & Vale de Cambra & 140.26 & 13 & 8.24 & 75 & 52.86 & 29 & 27.78 & 28 & 51.38 & 53 \\
\hline North & $\mathrm{M}$ & Bragança & 139.39 & 14 & 2.36 & 275 & 91.58 & 4 & 12.30 & 98 & 33.14 & 154 \\
\hline Azores & $\mathrm{S}$ & Lajes das Flores & 138.27 & 15 & 10.82 & 19 & 17.85 & 166 & -9.20 & 249 & 118.80 & 4 \\
\hline Central & $\mathrm{M}$ & Torres Vedras & 138.23 & 16 & 6.38 & 136 & 95.80 & 3 & 22.72 & 45 & 13.33 & 278 \\
\hline North & $\mathrm{L}$ & Porto & 136.44 & 17 & 5.88 & 156 & 39.80 & 54 & 58.68 & 6 & 32.09 & 162 \\
\hline Alentejo & $\mathrm{s}$ & Vendas Novas & 133.99 & 18 & 3.86 & 236 & 99.67 & 1 & 17.42 & 70 & 13.04 & 280 \\
\hline Central & $\mathrm{M}$ & Pombal & 132.74 & 19 & 8.60 & 61 & 39.20 & 56 & 18.15 & 66 & 66.80 & 23 \\
\hline Alentejo & $\mathrm{s}$ & Ourique & 129.98 & 20 & 8.98 & 46 & 26.14 & 108 & -4.42 & 222 & 99.27 & 6 \\
\hline North & $\mathrm{s}$ & Valença & 127.61 & 21 & 7.81 & 84 & 80.92 & 9 & 8.58 & 120 & 30.30 & 175 \\
\hline Central & $\mathrm{s}$ & Oliveira de Frades & 127.30 & 22 & 7.49 & 88 & 19.60 & 152 & 35.68 & 18 & 64.53 & 29 \\
\hline Alentejo & $\mathrm{s}$ & Grândola & 127.29 & 23 & 6.21 & 141 & 75.61 & 11 & 14.41 & 81 & 31.06 & 172 \\
\hline North & $\mathrm{s}$ & Melgaço & 127.22 & 24 & 5.61 & 166 & 47.43 & 36 & 17.10 & 72 & 57.08 & 40 \\
\hline Algarve & $\mathrm{M}$ & Albufeira & 125.33 & 25 & 1.69 & 288 & 38.87 & 58 & 7.06 & 126 & 77.71 & 11 \\
\hline Central & $\mathrm{s}$ & Vila Velha de Ródão & 124.03 & 26 & 8.91 & 50 & 36.74 & 67 & 34.89 & 19 & 43.48 & 89 \\
\hline Central & $\mathrm{L}$ & Leiria & 123.82 & 27 & 8.91 & 49 & 38.97 & 57 & 34.26 & 21 & 41.67 & 94 \\
\hline Central & $\mathrm{M}$ & Viseu & 122.53 & 28 & 8.06 & 79 & 71.46 & 13 & 15.85 & 75 & 27.16 & 201 \\
\hline Central & $\mathrm{S}$ & Vouzela & 121.62 & 29 & 8.64 & 58 & 50.74 & 32 & 0.84 & 175 & 61.39 & 34 \\
\hline Alentejo & $\mathrm{M}$ & Azambuja & 118.55 & 30 & 6.91 & 109 & 46.76 & 37 & 35.78 & 16 & 29.10 & 185 \\
\hline Central & $\mathrm{M}$ & Aveiro & 117.65 & 31 & 5.02 & 193 & 74.93 & 12 & 40.99 & 9 & -3.29 & 293 \\
\hline
\end{tabular}


Table A3. CSI sustainability results (Top 10\% worst performers).

\begin{tabular}{|c|c|c|c|c|c|c|c|c|c|c|c|c|}
\hline \multicolumn{13}{|c|}{ Non-Sustainable Councils-Worst $10 \%$ Performers } \\
\hline Regions & Size & Councils & $\begin{array}{c}\text { Global } \\
\text { Ranking }\end{array}$ & $\begin{array}{l}\text { Council } \\
\text { Position }\end{array}$ & $\begin{array}{c}\text { Governance } \\
\text { Ranking }\end{array}$ & $\begin{array}{l}\text { Council } \\
\text { Position }\end{array}$ & $\begin{array}{c}\text { Government } \\
\text { Effectiveness } \\
\text { Ranking }\end{array}$ & $\begin{array}{l}\text { Council } \\
\text { Position }\end{array}$ & $\begin{array}{c}\text { Economic and Social } \\
\text { Development } \\
\text { Ranking }\end{array}$ & $\begin{array}{l}\text { Council } \\
\text { Position }\end{array}$ & $\begin{array}{l}\text { Financial } \\
\text { Sustainability } \\
\text { Ranking }\end{array}$ & $\begin{array}{l}\text { Council } \\
\text { Position }\end{array}$ \\
\hline Algarve & $\mathrm{s}$ & Vila Real de Santo António & -898.68 & 308 & 6.36 & 138 & 45.41 & 41 & 4.00 & 155 & -954.45 & 308 \\
\hline North & $\mathrm{s}$ & Alijó & -289.57 & 307 & 4.05 & 227 & -42.28 & 297 & -6.76 & 238 & -244.59 & 307 \\
\hline Alentejo & $\mathrm{s}$ & Mourão & -131.47 & 306 & 5.10 & 190 & -61.12 & 304 & -39.06 & 305 & -36.40 & 298 \\
\hline Central & $\mathrm{S}$ & Góis & -103.42 & 305 & 6.66 & 125 & -147.61 & 308 & -2.94 & 215 & 40.47 & 104 \\
\hline North & $\mathrm{s}$ & Freixo de Espada à Cinta & -76.70 & 304 & 5.78 & 160 & -5.16 & 264 & -20.70 & 290 & -56.62 & 301 \\
\hline North & $\mathrm{s}$ & Santa Marta de Penaguião & -76.38 & 303 & 10.02 & 27 & -100.17 & 305 & -27.52 & 299 & 41.29 & 95 \\
\hline Central & $\mathrm{s}$ & Ferreira do Zêzere & -75.78 & 302 & 8.68 & 57 & -134.41 & 307 & 11.11 & 106 & 38.84 & 116 \\
\hline Madeira & $\mathrm{M}$ & Santa Cruz & -66.80 & 301 & 6.79 & 118 & 29.69 & 92 & -0.09 & 188 & -103.18 & 306 \\
\hline North & $\mathrm{M}$ & Chaves & -44.63 & 300 & 5.43 & 172 & 33.48 & 79 & -2.58 & 213 & -80.97 & 304 \\
\hline Central & $\mathrm{s}$ & Celorico da Beira & -43.30 & 299 & 3.81 & 240 & -112.24 & 306 & -1.86 & 204 & 66.99 & 22 \\
\hline North & $\mathrm{s}$ & Alfândega da Fé & -40.46 & 298 & 15.41 & 1 & 11.03 & 203 & -26.55 & 295 & -40.35 & 299 \\
\hline Alentejo & $\mathrm{s}$ & Gavião & -27.92 & 297 & 4.88 & 197 & -59.80 & 302 & -15.42 & 278 & 42.42 & 92 \\
\hline Azores & $\mathrm{s}$ & Nordeste & -27.29 & 296 & 9.47 & 38 & 6.06 & 226 & -7.99 & 243 & -34.84 & 296 \\
\hline Central & $\mathrm{s}$ & Idanha-a-Nova & -26.72 & 295 & 4.55 & 210 & -36.58 & 294 & -17.30 & 283 & 22.62 & 234 \\
\hline Lisbon & $\mathrm{L}$ & Seixal & -24.90 & 294 & 1.15 & 297 & 17.49 & 169 & 13.17 & 90 & -56.71 & 302 \\
\hline Central & $\mathrm{s}$ & Cadaval & -24.87 & 293 & 1.58 & 290 & -51.80 & 301 & 9.07 & 119 & 16.28 & 265 \\
\hline Madeira & $\mathrm{s}$ & Santana & -19.69 & 292 & 3.82 & 238 & -60.78 & 303 & -14.01 & 271 & 51.28 & 55 \\
\hline North & $\mathrm{s}$ & Vinhais & -19.02 & 291 & 8.69 & 55 & -33.34 & 292 & -24.16 & 294 & 29.79 & 179 \\
\hline Madeira & $\mathrm{s}$ & Ponta do Sol & -16.50 & 290 & 0.68 & 300 & -40.37 & 296 & -13.30 & 268 & 36.48 & 132 \\
\hline Central & $\mathrm{s}$ & Pedrógão Grande & -13.57 & 289 & 4.83 & 203 & -47.10 & 299 & -6.64 & 234 & 35.33 & 141 \\
\hline Algarve & $\mathrm{s}$ & Alcoutim & -13.13 & 288 & 8.54 & 65 & -16.07 & 280 & -6.79 & 239 & 1.18 & 292 \\
\hline North & $\mathrm{M}$ & Vizela & -12.61 & 287 & 11.07 & 16 & 39.92 & 53 & 10.60 & 110 & -74.19 & 303 \\
\hline Central & $\mathrm{s}$ & Santa Comba Dão & -12.31 & 286 & 4.34 & 218 & 17.77 & 167 & 1.83 & 167 & -36.25 & 297 \\
\hline North & $\mathrm{s}$ & Terras de Bouro & -10.51 & 285 & 3.99 & 230 & -17.47 & 281 & -28.48 & 300 & 31.45 & 170 \\
\hline North & $\mathrm{s}$ & Baião & -6.88 & 284 & 11.48 & 13 & -3.86 & 261 & -40.57 & 306 & 26.07 & 214 \\
\hline North & $\mathrm{s}$ & Cinfães & -5.73 & 283 & 5.52 & 170 & 6.69 & 222 & -44.10 & 307 & 26.16 & 213 \\
\hline Central & $\mathrm{s}$ & Vila Nova de Poiares & -3.35 & 282 & 9.76 & 31 & -14.32 & 279 & 7.02 & 128 & -5.80 & 294 \\
\hline Algarve & $\mathrm{M}$ & Faro & -3.01 & 281 & 1.79 & 285 & 57.72 & 24 & 35.74 & 17 & -98.26 & 305 \\
\hline Alentejo & $\mathrm{s}$ & Alandroal & -2.66 & 280 & 9.71 & 34 & -11.48 & 275 & -17.94 & 284 & 17.05 & 263 \\
\hline Central & $\mathrm{s}$ & Mação & 1.51 & 279 & 9.22 & 42 & -32.86 & 291 & 0.72 & 176 & 24.44 & 221 \\
\hline Alentejo & $\mathrm{s}$ & Viana do Alentejo & 5.07 & 278 & 7.56 & 87 & -25.33 & 285 & 1.98 & 165 & 20.86 & 246 \\
\hline
\end{tabular}




\section{References}

1. United Cities and Local Governments. Local Government Finance: The Challenges of the 21st Century; Second Global Report on Decentralization and Local Democracy; United Cities and Local Governments: Barcelona, Spain, 2010. Available online: https:/ / www.citiesalliance.org/sites/citiesalliance.org/files/CA_Images / UCLG_GOLDII_ExecutiveSummary.pdf (accessed on 28 December 2018).

2. Devas, N.; Delay, S. Local democracy and the challenges of decentralising the state: An international perspective. Local Gov. Stud. 2006, 32, 677-2007. [CrossRef]

3. Cruz, N.; Marques, R. Scorecards for sustainable local governments. Cities 2014, 39, 165-170. [CrossRef]

4. Portugal. Documento Verde da Reforma da Administração Local: Uma Reforma de Gestão, uma Reforma de Território e uma Reforma Política (in Portuguese); Minister of Parliamentary Affairs: Lisbon, Portugal, 2011.

5. NADC. European Union Funds; Annual Report 2014; National Agency for Development and Cohesion: Lisbon, Portugal, 2016.

6. Monfort, M.; Cuestas, J.C.; Ordonez, J. Real convergence in Europe: A cluster analysis. Econ. Model. 2013, 33, 689-694. [CrossRef]

7. Moro, B. Lessons from the European economic and financial great crisis: A survey. Eur. J. Political Econ. 2014, 34, S9-S24. [CrossRef]

8. Borsi, M.T.; Metiu, N. The evolution of economic convergence in the European Union. Empir. Econ. 2015, 48, 657-681. [CrossRef]

9. Scipioni, A.; Mazzi, A.; Zuliani, F.; Mason, M. The ISO 14031 standard to guide the urban sustainability measurement process: An Italian experience. J. Clean. Prod. 2008, 16, 1247-1257. [CrossRef]

10. Bachtler, J.; Wren, C. Evaluation of European Union cohesion policy: Research questions and policy challenges. Reg. Stud. 2006, 40, 143-153. [CrossRef]

11. Sala-i-Martin, X.X. Regional cohesion: Evidence and theories of regional growth and convergence. Eur. Econ. Rev. 1996, 40, 1325-1352. [CrossRef]

12. Delhey, J. The prospects of catching up for new EU members lessons for the accession countries to the European Union from previous enlargements. Soc. Ind. Res. 2001, 56, 205-231. [CrossRef]

13. Boldrin, M.; Canova, F.; Pischke, J.S.; Puga, D. Inequality and convergence in Europe's regions: Reconsidering European regional policies. Econ. Policy 2001, 16, 205 and 207-253. [CrossRef]

14. Atkinson, T.; Cantillon, B.; Marlier, E.; Nolan, B. Social Indicators: The EU and Social Inclusion; Oxford University Press: Oxford, UK, 2002.

15. Ederveen, S.; de Groot, H.L.F.; Nahuis, R. Fertile Soil for the Structural Funds? A Panel Data Analysis of the Conditional Effectiveness of European Cohesion Policy; CPB Netherlands Bureau for Economic Policy Analysis: The Hague, The Netherlands, 2002.

16. Cappelen, A.; Castellacci, F.; Fagerberg, J.; Verspagen, B. The impact of EU regional support on growth and convergence in the European Union. JCMS 2003, 41, 621-644. [CrossRef]

17. Beugelsdijk, M.; Eijffinger, S.C. The effectiveness of structural policy in the European Union: An empirical analysis for the EU-15 in 1995-2001. JCMS 2005, 43, 37-51. [CrossRef]

18. Dall'Erba, S.; Le Gallo, J. Regional convergence and the impact of European structural funds over 1989-1999: A spatial econometric analysis. Pap. Reg. Sci. 2008, 87, 219-244. [CrossRef]

19. Fritsche, U.; Kuzin, V. Analysing convergence in Europe using the non-linear single factor model. Empir. Econ. 2011, 41, 343-369. [CrossRef]

20. Bartkowska, M.; Riedl, A. Regional convergence clubs in Europe: Identification and conditioning factors. Econ. Model. 2012, 29, 22-31. [CrossRef]

21. Christoph, B.; Noll, H.H. Subjective well-being in the European Union during the 90s. In European Welfare Production; Springer: Dordrecht, The Netherlands, 2003; pp. 197-222.

22. Diener, E.; Suh, E. Measuring quality of life: Economic, social, and subjective indicators. Soc. Ind. Res. 1997, 40, 189-216. [CrossRef]

23. Caldas, P.; Dollery, B.; Marques, R.C. What really matters concerning local government evaluation: Community Sustainability? Lex Localis J. Local Self-Gov. 2016, 14, 279-304. [CrossRef]

24. Bartelmus, P. Use and usefulness of sustainability economics. Ecol. Econ. 2010, 69, 2053-2055. [CrossRef]

25. IUCN, U. World Conservation Strategy: Living Resource Conservation for Sustainable Development; International Union for the Conservation of Nature and Natural Resources (IUCN): Gland, Switzerland, 1980. 
26. Brundtland, G.H. World commission on environment and development. Environ. Policy Law 1985, 14, $26-30$.

27. Dollery, B.E.; Kortt, M.; Grant, B. Funding the Future, Financial Sustainability and Infrastructure Finance in Australian Local Government; The Federation Press: Sydney, Australia, 2013.

28. Pires, S.M.; Fidélis, T. Local sustainability indicators in Portugal: Assessing implementation and use in governance contexts. J. Clean. Prod. 2015, 86, 289-300. [CrossRef]

29. Vetter, A.; Kersting, N. Democracy versus efficiency? Comparing local government reforms across Europe. In Reforming Local Government in Europe; VS Verlag für Sozialwissenschaften: Wiesbaden, Germany, 2003; pp. 11-28.

30. Aulich, C. Australia: Still a tale of Cinderella? In Comparing Local Governance: Trends and Developments; Palgrave Macmillan: Basingstoke, UK, 2005; pp. 193-210.

31. Dollery, B.E.; Garcea, J.; Lesage, E. Local Government Reform: A Comparative Analysis of Advanced Anglo-American Countries; Edward Elgar: Cheltenham, UK, 2008.

32. Dollery, B.E.; Crase, L.; Grant, B. The local capacity, local community and local governance dimensions of sustainability in Australian local government. Commonw. J. Local Gov. 2011. [CrossRef]

33. Bell, S.; Morse, S. Measuring Sustainability: Learning from Doing; Routledge: London, UK, 2013.

34. Warburton, D. Community and Sustainable Development: Participation in the Future; Routledge: London, UK, 2013.

35. Wates, N. The Community Planning Handbook: How People Can Shape Their Cities, Towns E Villages in Any Part of the World; Routledge: London, UK, 2014.

36. Ammons, D. Municipal Benchmarks: Assessing Local Performance and Establishing Community Standards; M.E. Sharpe: Armonk, NY, USA, 2012.

37. Andrews, M.; Hay, R.; Myers, J. Can governance indicators make sense? Towards a new approach to sector-specific measures of governance. Oxf. Dev. Stud. 2010, 38, 391-410. [CrossRef]

38. Ferreira, D.C.; Marques, R.C. Malmquist and Hicks-Moorsteen Productivity Indexes for Clusters Performance Evaluation. Int. J. Inf. Technol. Decis. Mak. 2016, 15, 1015-1053. [CrossRef]

39. Charnes, A.; Cooper, W.W.; Lewin, A.Y.; Morey, R.C.; Rousseau, J. Sensitivity and stability analysis in DEA. Ann. Oper. Res. 1985, 2, 139-150. [CrossRef]

40. Aragon, Y.; Daouia, A.; Thomas-Agnan, C. Nonparametric frontier estimation: A Conditional quantile-based approach. Econ. Theory 2005, 21, 358-389. [CrossRef]

41. Ferreira, D.C.; Marques, R.C. Did the corporatization of Portuguese hospitals significantly change their productivity? Eur. J. Health Econ. 2015, 16, 289-303. [CrossRef] [PubMed]

42. Daraio, C.; Simar, L. Directional distances and their robust versions: Computational and testing issues. Eur. J. Oper. Res. 2014, 237, 358-369. [CrossRef]

43. Portela, M.C.A.S.; Thanassoulis, E. Malmquist indexes using a Geometric Distance Function (GDF). Application to a sample of Portuguese bank branches. J. Prod. Anal. 2006, 25, 25-41. [CrossRef]

44. Moorsteen, R.H. On measuring productive potential and relative efficiency. Q. J. Econ. 1961, 75, 451-467. [CrossRef]

45. Minister of Parliamentary Affairs. Livro Branco do Sector Empresarial Local (in Portuguese); Minister of Parliamentary Affairs: Lisbon, Portugal, 2011.

46. Pinto, F.; Da Cruz, N.; Marques, R.C. Contracting water services with public and private partners: A case study approach. J. Water Supply Res. Technol. AQUA 2015, 64, 194-210. [CrossRef]

47. European Commission. A New Partnership for Cohesion: Convergence, Competitiveness, Cooperation; Third Report on Economic and Social Cohesion; Office for Official Publications of the European Communities: Luxembourg, 2004.

48. Afonso, A.; Fernandes, S. Assessing and explaining the relative efficiency of local government. J. Socio-Econ. 2008, 37, 1946-1979. [CrossRef]

49. Troschinetz, A.M.; Mihelcic, J.R. Sustainable recycling of municipal solid waste in developing countries. Waste Manag. 2009, 29, 915-923. [CrossRef] [PubMed]

50. Caragliu, A.; Del Bo, C.; Nijkamp, P. Smart cities in Europe. J. Urban Technol. 2011, 18, 65-82. [CrossRef]

51. Ache, P.; Andersen, H.T.; Maloutas, T.; Raco, M.; Tasan-Kok, T. Cities between Competitiveness and Cohesion: Discourses, Realities and Implementation; Springer: New York, NY, USA, 2008.

52. Sapelli, C.; Vial, B. The performance of private and public schools in the Chilean voucher system. Cuad. Econ. 2002, 39, 423-454. [CrossRef] 
53. Zeller, M.; Sharma, M.; Henry, C.; Lapenu, C. An operational method for assessing the poverty outreach performance of development policies and projects: Results of case studies in Africa, Asia, and Latin America. World Dev. 2006, 34, 446-464. [CrossRef]

54. Nyhan, R.C.; Martin, L.L. Assessing the performance of municipal police services using data envelopment analysis: An exploratory study. State Local Gov. Rev. 1999, 31, 18-30. [CrossRef]

55. Benito, B.; Bastida, F. The determinants of the municipal debt policy in Spain. J. Public Budg. Account. Financ. Manag. 2004, 16, 492-525. [CrossRef]

56. Buettner, T.; Wildasin, D.E. The dynamics of municipal fiscal adjustment. J. Public Econ. 2006, 90, 1115-1132. [CrossRef]

(C) 2018 by the authors. Licensee MDPI, Basel, Switzerland. This article is an open access article distributed under the terms and conditions of the Creative Commons Attribution (CC BY) license (http:/ / creativecommons.org/licenses/by/4.0/). 